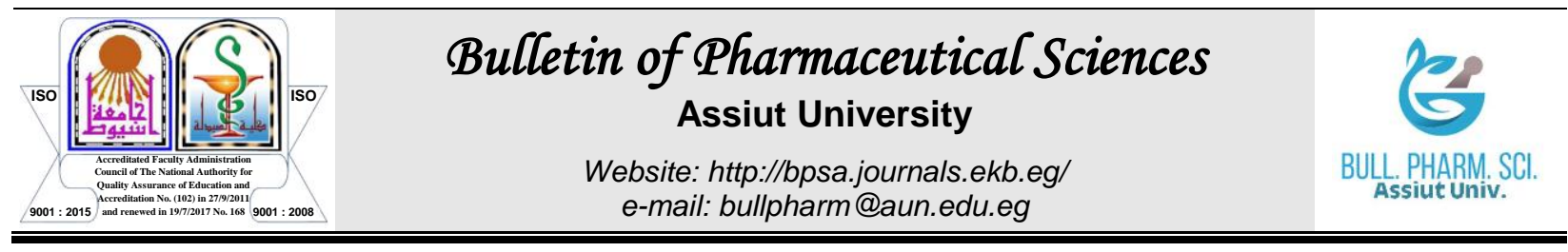

\title{
THE CLINICAL EFFICACY OF DESLORATADINE, A NON-SEDATING ANTIHISTAMINE, IN THE MANAGEMENT OF ALLERGIC CONDITIONS: A REVIEW OF THE EVIDENCE
}

\author{
Aida Sefidani Forough ${ }^{1}$, Atefeh Fakharian ${ }^{2 *}$, Sahar Faraji Joubani ${ }^{3}$, Alireza Afsari ${ }^{3}$, Parsa Riazi \\ Esfahani $^{4}$ and Fanak Fahimi ${ }^{5,6}$ \\ ${ }^{1}$ School of Clinical Sciences, Faculty of Health, Queensland University of Technology (QUT), \\ Brisbane, Queensland, Australia \\ ${ }^{2}$ Chronic Respiratory Diseases Research Centre (CRDRC), National Research Institute of \\ Tuberculosis and Lung Diseases (NRITLD), Shahid Beheshti University of Medical Sciences, \\ Tehran, Iran \\ ${ }^{3}$ Department of Medical Affairs, Abidi Pharmaceuticals, Tehran, Iran \\ ${ }^{4}$ Neuroscience Interdepartmental Program, University of California, Los Angeles, California, \\ USA \\ ${ }^{5}$ American Career College, California, USA \\ ${ }^{6}$ Department of Clinical Pharmacy, Faculty of Pharmacy, Shahid Beheshti University of \\ Medical Sciences, Tehran, Iran
}

\begin{abstract}
Desloratadine is a relatively new, second-generation, tricyclic antihistamine which came into medical use in 2001. This study aimed to review the available evidence in the literature around the clinical efficacy of desloratadine on a range of allergic conditions. A database search in Medline, PubMed, Embase, and Google Scholar was conducted for the research articles published until July 2020, using the keyword desloratadine. An additional reference lists search and citation tracking were also performed. Research articles in English pertaining to desloratadine and its efficacy were considered for inclusion. Study designs, including randomized controlled trials (RCT), observational/case-control studies, and case series were considered. The collective evidence from the current literature shows superior efficacy of desloratadine compared to placebo and some of the other treatment options in the management of seasonal allergic rhinitis (SAR), perennial allergic rhinitis (PAR), chronic idiopathic urticaria (CIU), and asthmatic symptoms. There is also evidence for potential new roles introduced for desloratadine such as acne treatment, chronic otitis media, and chronic rhinosinusitis, which warrants further investigation. In most studies, desloratadine's safety and tolerability were comparable with placebo. Current evidence suggest that desloratadine is an ideal option for most of the allergic conditions due to its efficacy as well as favourable safety and tolerability profile. Further large-scale studies are needed to establish the efficacy and safety profile of desloratadine and to compare its effectiveness against other treatments in the management of allergic conditions.
\end{abstract}

\section{INTRODUCTION}

Upon the introduction of secondgeneration $\mathrm{H} 1$-antihistamines, the use of firstgeneration antihistamines became limited due to their high penetration across the blood-brain barrier resulting in sedation, impaired cognitive function, and reduced quality of life (QoL).
Currently, second generation non-sedating antihistamines are recommended as a first-line therapy by many international therapeutic guidelines for the management of allergic disorders such as allergic rhinitis and chronic idiopathic urticaria.

Among the second generation H1antihistamines, desloratadine is a relatively

Received in 7/3/2021 \& Accepted in 27/5/2021 
new agent which was first approved in 2001 by the US Food and Drug Administration with an indication for allergic rhinitis (AR). Currently, it is indicated for all types of AR irrespective of conventional classification (i.e. seasonal/perennial) or the more recent Allergic Rhinitis and its Impact on Asthma (ARIA) classification (i.e. intermittent or persistent) in both adult and paediatric populations. Its indication has also been approved for the treatment of chronic idiopathic urticaria although other indications have also been introduced for this medication. This study aimed to review the current evidence around the clinical efficacy of desloratadine, in the management of a variety of allergic conditions.

\section{Methods and Search Strategy}

An initial scoping search was conducted in Google Scholar to determine the potential keywords. A database search was then conducted in Embase, Medline, PubMed, and Google Scholar for the published literature. Research articles in English published between 2001 and July 2020 were considered for this review. The review included the original research with a variety of methodologies, including randomized controlled trials (RCTs), observational/case-control studies, retrospective evaluations, case series, and short communication reports. Case reports, abstracts, letters to the editor, reviews, meta-analyses, and expert opinions were excluded. Moreover, in-vitro pharmacological studies as well as invivo clinical studies on healthy volunteers without an allergic pathology were also not considered. Wherever possible, a complementary reference list search and citation tracking were also performed to include any articles that might have been missed in the initial database search.

\section{Seasonal or Intermittent Allergic Rhinitis Desloratadine vs. Placebo}

Studies have documented efficacy of desloratadine in improving all parameters related to seasonal allergic rhinitis (SAR) symptom scores, including total symptom scores (TSS), total nasal symptom scores (TNSS), and total non-nasal symptom scores (TNNSS) compared to placebo (Table 1$)^{2-9}$.

Looking at individual symptoms, desloratadine was found to attain superior efficacy in decreasing the nasal symptom scores resulting in marked improvement in the severity of nasal congestion, rhinorrhoea, and sneezing ${ }^{7 \& 10 \& 11}$. Similarly, the overall and individual ocular symptoms, including eye tearing, burning/itching, and eye redness have reportedly experienced significant reduction with desloratadine ${ }^{7 \& 10}$. Dermal symptoms, as well as total symptom scores also decreased significantly with desloratadine treatment ${ }^{10}$. Another study indicated that symptoms including nasal discharge, nasal itching, and sneezing as well as eye redness, itchy ears, throat, and palate in the morning and evening showed significantly greater decline ${ }^{5}$. According to the findings of a post-marketing surveillance, desloratadine treatment resulted in significant reduction in all TSS and individual symptom scores (including nasal, ocular, dermal, and asthma symptom scores) compared to baseline ${ }^{12}$.

Looking at the evidence around nasal congestion and patency measures, the efficacy of daily desloratadine $5 \mathrm{mg}$ on improving the nasal airflow in patients with grass pollen SAR was studied ${ }^{2}$. Patients treated with desloratadine had a significantly less drop in their nasal airflow after exposure to grass pollen allergen than the placebo and over the entire exposure time. The combined findings of three separate RCTs enrolling 948 patients with SAR indicated a significant reduction in the average reflective morning and afternoon nasal congestion severity scores with desloratadine daily treatment over a 2 -week treatment that sustained for four weeks ${ }^{13}$. Other RCTs confirm these findings where administration of desloratadine to patients with SAR/IAR significantly improved nasal congestion/stuffiness, reduced nasal congestion scores, and improved nasal airflow compared to placebo ${ }^{11 \& 14}$. The decongestant effects of desloratadine were observed from day 2 of the trial and sustained over the 2-weeks of the study period ${ }^{14}$. The superior efficacy of desloratadine in comparison with placebo was demonstrated in another RCT in which the efficacy of desloratadine on improving nasal patency measures among 218 patients with SAR was studied ${ }^{5}$. The assessment of nasal patency parameters indicated a significantly greater descending expiratory nasal airflow in the desloratadine group, but non-significant increase in the nasal airflow at the ascending inspiratory phase. Further, the placebo group 
experienced a significantly larger increase in the total inspiratory nasal airway resistance compared with desloratadine treatment ${ }^{5}$. In a prospective study of 602 patients, nasal congestion measures indicated by peak nasal inspiratory flow (PNIF) also improved with desloratadine compared to the baseline measures ${ }^{7}$. In one study, however, although numerically improved, the mean nasal inspiratory flow scores did not show a significant improvement with desloratadine ${ }^{9}$.

Subjective patient and physician reports have also provided insights into the effectiveness of desloratadine therapy in SAR. Through the subjective assessment of efficacy nearly $65 \%$ of both physician and patient respondents stated that the onset of action of desloratadine was faster than their previous treatment with other antihistamines ${ }^{10}$. When assessed for the interference of their allergic disorder with sleep patterns and activities of daily life, taking desloratadine resulted in significant improvement in sleep and daily activities of SAR patients ${ }^{10 \& 12}$. One study employed a patient subjective assessment of the allergic symptoms using a visual analogue scale (VAS). The VAS rating of symptoms also indicated a significant reduction in desloratadine group ${ }^{8}$. More than $85 \%$ of the subjects in one study reported complete or marked relief of their allergic symptoms with the use of desloratadine compared to baseline ${ }^{7}$.

The impact of desloratadine therapy on SAR patients' QoL has been the focus of some studies. The outcomes of these studies are generally in agreement that patients treated with desloratadine demonstrated significantly greater improvements in QoL scores compared to placebo as measured by common tools like Rhinoconjunctivitis Quality of Life Questionnaire (RQLQ) $)^{4-5 \& 8-9}$.

\section{Desloratadine vs. other treatment agents}

The superior efficacy of both desloratadine and diphenhydramine in improving the TSS as well as TNSS of AR was reported when compared to placebo ${ }^{15}$. Diphenhydramine also showed superior efficacy than placebo in improving the TNNSS, the TSS, TNSS, and individual symptom scores, including nasal congestion in comparison with desloratadine ${ }^{15 \& 16}$. However, diphenhydramine, had the highest percentage of adverse effects (AEs) reported, compared to desloratadine and placebo $(35 \%, 16 \%$, and $8 \%$, respectively) with somnolence being the most common $\mathrm{AE}^{16}$. Also, diphenhydramine treatment was associated with significantly meaningful impairment in all the studied cognitive parameters including vigilance, psychomotor speed, working memory, reasoning/computation, and divided attention compared to desloratadine ${ }^{15}$.

Another RCT evaluated the efficacy of once daily desloratadine $5 \mathrm{mg}$ and rupatadine $10 \mathrm{mg}$ in patients diagnosed with $\mathrm{SAR}^{17}$. Overall, both drugs showed superior efficacy compared to placebo in reducing the total symptoms score of SAR as well as significantly improving both nasal and non-nasal symptoms ${ }^{17}$. There was no clinically significant superiority between the two active agents, although the symptom reduction was slightly better with desloratadine than rupatadine $(49 \%$ vs. $46 \%$ ).

In another RCT, azelastine was shown to have superior efficacy compared to desloratadine and placebo after 4-6 hours of administration although desloratadine, was also significantly more effective than placebo $^{18}$. Moreover, azelastine showed a faster decrease in both TNSS and major nasal symptoms score with an onset of action of $15 \mathrm{~min}$. versus 150 min. for desloratadine. Azelastine also showed significantly better results compared to desloratadine in investigator-scored outcomes with $74 \%$ satisfactory outcomes compared to $56 \%$ for desloratadine ${ }^{18}$.

A comparative RCT examined the clinical efficacy as well as the onset and duration of action of once daily desloratadine $5 \mathrm{mg}$ against levocetirizine $5 \mathrm{mg}$ in patients with ragweedinduced $\mathrm{AR}^{19}$. The findings of this trial showed both medications acted significantly better than placebo. However, greater improvement was produced by levocetirizine in a 24-hrs. period, compared to desloratadine in alleviating major symptoms such as nose blows, sneezes, runny nose, itchy nose, watery eye and $\mathrm{TSS}^{19}$. Moreover, nasal congestion was found to resolve to a greater extent with levocetirizine than desloratadine while desloratadine did not show a significant alleviation of nasal congestion in comparison to placebo. Levocetirizine also showed advantages in terms of faster onset of action compared to desloratadine ( $1 \mathrm{hr}$ vs. $3 \mathrm{hrs}){ }^{19}$. Another RCT compared the efficacy of a single dose of 
levocetirizine $5 \mathrm{mg}$ and desloratadine $5 \mathrm{mg}$ in 24 patients with grass-pollen allergy and rhinitis $^{50}$. Levocetirizine was more successful than desloratadine in inhibiting the sneezing and rhinorrhoea while none of the substances were able to inhibit nasal congestion significantly ${ }^{20}$. Albumin extravasation, as an early allergic marker in the nasal lavage, was significantly inhibited by levocetirizine, but not desloratadine $^{20}$.

Using a similar methodology, Bhatia et $a l^{21}$ compared the effects of daily oral desloratadine and nasal budesonide for two weeks on improving nasal peak inspiratory flow (NPIF) in subjects with a history of seasonal allergy to tree or grass pollens. During the two-week study period, nasal budesonide worked better than desloratadine in terms of the number of days with an improved morning, evening, and overall NPIF values from baseline $^{21}$. While both medications appeared to significantly alleviate the symptom scores compared to their baseline, no significant differences between two medications were detected in this regard ${ }^{21}$.

Desloratadine efficacy was further investigated in a comparative study comparing it against ketotifen fumarate ophthalmic solution or their combination in resolving seasonal allergic rhino-conjunctivitis ${ }^{22}$. When evaluated for the ocular symptoms after four weeks, the subjects in the ketotifen or ketotifen/desloratadine combination group attained significantly lower mean ocular itching scores compared to the desloratadine group alone. Comparatively, the ketotifen therapy alone resulted in significantly less ocular redness compared with desloratadine and ketotifen/desloratadine combination at 15 and 20 -min time points after allergen induction ${ }^{22}$. When assessed for the amount of tear production, desloratadine treatment resulted in less tearing compared with other groups, though such difference did not achieve statistical significance. The study suggested that using ophthalmic ketotifen in combination with oral desloratadine shows higher efficacy in rhino-conjunctivitis than using desloratadine alone ${ }^{22}$.

Bachert $e t$ al. ${ }^{23}$ compared the efficacy and safety of desloratadine and bilastine in relieving SAR. Through a randomized double- blind, placebo-controlled, parallel-group trial, the study subjects received once daily doses of desloratadine $5 \mathrm{mg}$, bilastine $20 \mathrm{mg}$, or placebo over a 2-week period. According to the findings, both desloratadine and bilastine significantly, but comparably improved TSS, NSS, and NNSS compared to placebo. Similarly, both treatments were equally effective in increasing the RQLQ measures ${ }^{23}$. Looking at the individual domains of QoL, bilastine demonstrated effectiveness except for nasal symptoms, emotional, and sleep components, while desloratadine did not have significant efficacy on nasal symptoms and emotional components ${ }^{23}$.

Through an ad hoc analysis, Bachert \& Maurer $^{12}$, also made a comparison of desloratadine treatment with any previous monotherapy with another second-generation antihistamine. In this subjective assessment, most of the participants (ranging between $60 \%$ $88 \%$ ) reported the efficacy of desloratadine to be higher than cetirizine, loratadine, fexofenadine, and mizolastine ${ }^{12}$.

Berger et al. $^{24}$ compared the efficacy of desloratadine $5 \mathrm{mg} /$ day, fexofenadine 180 $\mathrm{mg} / \mathrm{d}$, and placebo among 722 patients presenting with symptomatic SAR. The analyses of morning instantaneous TSS and morning/evening reflective TSS indicated superior efficacy of both desloratadine and fexofenadine treatments to placebo, while demonstrating the comparative efficacy between the two active treatments. Moreover, both fexofenadine and desloratadine were associated with significant improvements in morning instantaneous individual symptoms, including sneezing and itchy nose, throat, and palate $^{24}$. Desloratadine demonstrated a further advantage in this regard than fexofenadine by significantly alleviating the ocular symptoms such as itchy, watery, and red eyes while fexofenadine failed to achieve a significant improvement in these symptoms. Desloratadine provided further advantage in morning/evening symptoms by statistically reducing the severity score of rhinorrhoea compared to fexofenadine ${ }^{24}$. The numerical assessment of the patient and investigator assessed the subjective efficacy also showed an improving trend throughout the 15 days of study. 
Table 1: An overview of research studies on clinical efficacy of desloratadine either compared to placebo , baseline measures, or other treatment agents in treatment of seasonal or intermittent allergic rhinitis

\begin{tabular}{|c|c|c|c|c|c|}
\hline $\begin{array}{l}\text { Authors/ } \\
\text { year }\end{array}$ & Methodology & Inclusion criteria & $\begin{array}{l}\text { No. of } \\
\text { patients }\end{array}$ & $\begin{array}{l}\text { Comparator } \\
\text { regimen }(\mathrm{s})\end{array}$ & Outcomes and results \\
\hline $\begin{array}{l}\text { Salmun \& } \\
\text { Lorber/ } \\
2002\end{array}$ & $\begin{array}{l}\text { Randomized, } \\
\text { multic enter, } \\
\text { parallel-group, } \\
\text { placebo- } \\
\text { controlled, } \\
\text { double-blind } \\
\text { trial }\end{array}$ & $\begin{array}{l}\geq 12 \text { years old; } 2 \text {-year } \\
\text { history of SAR }\end{array}$ & $1,1,036$ & $\begin{array}{l}\text { Desloratadine } \\
2.5,5,7.5,10, \\
20 \mathrm{mg} \\
\text { Placebo }\end{array}$ & $\begin{array}{l}\text { Significantly superior to placebo } \\
\text { in morning instantaneous TSS } \\
\text { score for all doses. } \\
\text { Significantly effective than } \\
\text { placebo in improving } \\
\text { morning/evening TNSS and } \\
\text { TNNSS. } \\
\text { Significant 24-hour relief of SAR } \\
\text { symptoms compared to placebo. } \\
\text { Significant improvement in all } \\
\text { individual symptoms including } \\
\text { the nasal and non-nasal } \\
\text { symptoms. }\end{array}$ \\
\hline $\begin{array}{l}\text { Horak et } \\
\text { al./ } 2002\end{array}$ & $\begin{array}{l}\text { Randomized, } \\
\text { double-blind, } \\
\text { placebo } \\
\text { controlled, } \\
\text { crossover trial }\end{array}$ & $\begin{array}{l}19 \text { to } 45 \text { years old; } \\
\text { SAR } \geq 2 \text { years; } \\
\text { positive skin prick test } \\
\text { response to grass } \\
\text { pollen; } \\
\text { radioallergosorbent } \\
\text { test of class } 2 \text { or } \\
\text { greater at screening or } \\
\text { during the previous } \\
12 \text { months }\end{array}$ & 47 & $\begin{array}{l}\text { Desloratadine } \\
5 \mathrm{mg} / \text { day } \\
\text { Placebo } \\
\text { (For } 7 \text { days) }\end{array}$ & $\begin{array}{l}\text { Significant efficacy in relieving } \\
\text { nasal obstruction and increasing } \\
\text { the nasal airflow. } \\
\text { Significantly lower individual and } \\
\text { overall SAR symptom severity } \\
\text { scores including sneezing and } \\
\text { nasal congestion. } \\
\text { Relatively better nasal airflow, } \\
\text { less nasal secretions, and less } \\
\text { nasal congestion after allergen } \\
\text { exposure. }\end{array}$ \\
\hline $\begin{array}{l}\text { Horak et } \\
\text { al./ } 2003\end{array}$ & $\begin{array}{l}\text { Randomized } \\
\text { double-blind } \\
\text { placebo- } \\
\text { controlled } \\
\text { crossed over } \\
\text { study }\end{array}$ & $\begin{array}{l}\text { SAR for } \geq 2 \text { years; } \\
\text { responder to } \\
\text { antihistamine } \\
\text { treatment; positive } \\
\text { skin prick test to grass } \\
\text { pollen; a positive } \\
\text { radioallergosorbent } \\
\text { test (class } \geq 2 \text { ) }\end{array}$ & 47 & $\begin{array}{l}\text { Desloratadine } \\
5 \mathrm{mg} / \text { day } \\
\text { Placebo }\end{array}$ & $\begin{array}{l}\text { Superior efficacy in maintaining } \\
\text { nasal airflow. } \\
\text { Significantly less increase in nasal } \\
\text { secretions. } \\
\text { Significantly lower SAR symptom } \\
\text { scores and nasal congestion. }\end{array}$ \\
\hline $\begin{array}{l}\text { Pradalier et } \\
\text { al./ } 2007\end{array}$ & $\begin{array}{l}\text { Multicenter, } \\
\text { double-blind, } \\
\text { randomized, } \\
\text { parallel-group } \\
\text { study }\end{array}$ & $\begin{array}{l}\geq 18 \text { years old; SAR } \geq \\
2 \text { years confirmed by } \\
\text { a positive skin prick } \\
\text { test to grass pollen } \leq \\
24 \text { months before or } \\
\text { at screening; having at } \\
\text { least moderate } \\
\text { seasonal AR (TSS } \geq \\
8, \text { nasal congestion } \\
\text { score } \geq 2, \text { and a } \\
\text { TNNSS } \geq 2 \text { ) }\end{array}$ & 483 & $\begin{array}{l}\text { Desloratadine } \\
5 \text { mg once } \\
\text { daily } \\
\text { Placebo }\end{array}$ & $\begin{array}{l}\text { Significantly greater } \\
\text { improvements in RQLQ scores } \\
\text { compared to placebo. } \\
\text { Significant improvement in all } \\
\text { individual domains of the QoL } \\
\text { assessment including nose } \\
\text { symptoms, eye symptoms, sleep } \\
\text { problems, practical problems, } \\
\text { activity limitation, general } \\
\text { problems, and emotional function. } \\
\text { Significant decrease in all TSS, } \\
\text { TNSS, and TNNSS of AR } \\
\text { compared with placebo. } \\
\text { AEs comparable with placebo. }\end{array}$ \\
\hline
\end{tabular}




\begin{tabular}{|c|c|c|c|c|c|}
\hline $\begin{array}{l}\text { Authors/ } \\
\text { year }\end{array}$ & Methodology & Inclusion criteria & $\begin{array}{l}\text { No. of } \\
\text { patients }\end{array}$ & $\begin{array}{l}\text { Comparator } \\
\text { regimen }(\mathrm{s})\end{array}$ & Outcomes and results \\
\hline $\begin{array}{l}\text { Bachert et } \\
\text { al./ } 2002\end{array}$ & $\begin{array}{l}\text { Observational, } \\
\text { post-marketing } \\
\text { surveillance } \\
\text { study }\end{array}$ & $\begin{array}{l}\text { Patients with } \\
\text { symptoms of SAR; } \\
\text { expected to remain in } \\
\text { the study for the } \\
\text { treatment period }\end{array}$ & 477,000 & $\begin{array}{l}\begin{array}{l}\text { Desloratadine } \\
\text { (dose not } \\
\text { specified) }\end{array} \\
\text { Baseline } \\
\text { Any other } \\
\text { previous } \\
\text { treatment (e.g. } \\
\text { loratadine, } \\
\text { cetirizine, } \\
\text { fexofenadine, } \\
\text { unspecified } \\
\text { drugs, or } \\
\text { multiple } \\
\text { treatments) }\end{array}$ & $\begin{array}{l}\text { Superior efficacy compared with } \\
\text { the baseline measures in } \\
\text { decreasing the total and individual } \\
\text { nasal symptom scores. } \\
\text { Significant improvement with } \\
\text { desloratadine in overall and } \\
\text { individual ocular symptoms. } \\
\text { Significant efficacy in alleviating } \\
\text { dermal and TSS. } \\
\text { Significant reduction in asthma } \\
\text { symptom scores in patients with } \\
\text { SAR and asthma and reduced } \\
\text { asthma medication use during the } \\
\text { desloratadine treatment period. } \\
\text { Reduction in moderate/severe } \\
\text { asthma symptoms including } \\
\text { wheezing, breathlessness, chest } \\
\text { tightness, and cough. }\end{array}$ \\
\hline $\begin{array}{l}\text { Lorber et } \\
\text { al./ } 2002\end{array}$ & $\begin{array}{l}\text { Combination of } \\
\text { three separate, } \\
\text { randomized, } \\
\text { double-blind, } \\
\text { placebo- } \\
\text { controlled, } \\
\text { parallel-group, } \\
\text { multicenter } \\
\text { studies }\end{array}$ & $\begin{array}{l}\geq 2 \text {-year history of } \\
\text { SAR; exacerbated } \\
\text { asthma symptoms } \\
\text { during allergy season; } \\
\text { positive skin test } \\
\text { response to } \\
\text { appropriate seasonal } \\
\text { allergens } \leq 24 \\
\text { months; at least } \\
\text { moderate rhinorrhea; } \\
\text { TNSS } \geq 6, \text { and } \\
\text { TNNSS of 5; FEV1 } \geq \\
70 \% ; \text { total frequency } \\
\text { of asthma score } \\
\text { and/or bronchodilator } \\
\text { use score }=2 ; \text { total } \\
\text { reflective scores for } 3 \\
\text { days prior to baseline } \\
=42 \text { for TNSS and }= \\
35 \text { for TNNSS; } \\
\text { demonstrated } \\
\text { reversibility in } \\
\text { patients with SAR and } \\
\text { asthma; clinically } \\
\text { significant disease- } \\
\text { free; negative serum } \\
\text { pregnancy test and } \\
\text { medically accepted } \\
\text { method of birth } \\
\text { control } \\
\end{array}$ & 948 & $\begin{array}{l}\text { Desloratadine } \\
5 \text { mg once } \\
\text { daily } \\
\text { Placebo }\end{array}$ & $\begin{array}{l}\text { Significant reduction in the } \\
\text { average reflective } \\
\text { morning/evening nasal congestion } \\
\text { severity scores compared to } \\
\text { placebo. } \\
\text { Significantly greater reduction in } \\
\text { the mean reflective nasal } \\
\text { congestion scores in a subgroup } \\
\text { analysis of patients with } \\
\text { concomitant SAR and asthma. } \\
\text { Similar safety profile to placebo. }\end{array}$ \\
\hline $\begin{array}{l}\text { Nayak and } \\
\text { Schenkel/ } \\
2001\end{array}$ & $\begin{array}{l}\text { Randomized, } \\
\text { placebo- } \\
\text { controlled, } \\
\text { double-blind } \\
\text { study }\end{array}$ & $\begin{array}{l}\text { At least moderate IAR } \\
\text { symptomatic at } \\
\text { screening and } \\
\text { baseline; both nasal } \\
\text { and nonnasal } \\
\text { symptoms present; } \geq \\
\text { 2-year history of IAR; } \\
\text { positive skin prick test } \\
\leq 1 \text { year; clinically } \\
\text { significant disease- } \\
\text { free }\end{array}$ & 346 & $\begin{array}{l}\text { Desloratadine } \\
5 \text { mg/daily } \\
\text { Placebo } \\
\text { (For two } \\
\text { weeks) }\end{array}$ & $\begin{array}{l}\text { Significant improvement of nasal } \\
\text { congestion/stuffiness and } \\
\text { reduction in the nasal congestion } \\
\text { scores compared to placebo. } \\
\text { Early onset of action and } \\
\text { sustainable efficacy over the study } \\
\text { period. } \\
\text { Placebo-like AE profile with no } \\
\text { severe AEs. }\end{array}$ \\
\hline
\end{tabular}




\begin{tabular}{|c|c|c|c|c|c|}
\hline $\begin{array}{l}\text { Authors/ } \\
\text { year }\end{array}$ & Methodology & Inclusion criteria & $\begin{array}{l}\text { No. of } \\
\text { patients }\end{array}$ & $\begin{array}{l}\text { Comparator } \\
\text { regimen(s) }\end{array}$ & Outcomes and results \\
\hline $\begin{array}{l}\text { Meltzer et } \\
\text { al./ } 2005\end{array}$ & $\begin{array}{l}\text { Randomized, } \\
\text { double-blind, } \\
\text { placebo } \\
\text { controlled, } \\
\text { single-center, } \\
\text { parallel-group } \\
\text { study }\end{array}$ & $\begin{array}{l}18-60 \text { years old, } \geq 2 \\
\text { years history of } \\
\text { mild/moderate SAR, } \\
\text { positive skin test } \\
\text { reaction to a seasonal } \\
\text { allergen within } 12 \\
\text { months, combined } \\
\text { NSS } \geq 6, \text { nasal } \\
\text { congestion score of } \geq \\
2, \text { and TSS } \geq 11 \text { for } \\
\text { at least } 3 / 5 \text { of the } \\
\text { preceding morning } \\
\text { scores, not having } \\
\text { significant disease }\end{array}$ & 218 & $\begin{array}{l}\text { Desloratadine } \\
5 \text { mg daily } \\
\text { Placebo } \\
\text { (For two } \\
\text { weeks) }\end{array}$ & $\begin{array}{l}\text { Significantly greater decrease than } \\
\text { placebo in joint patient and } \\
\text { investigator-rated symptom } \\
\text { scores. } \\
\text { Significant decrease in the } \\
\text { sneezing scores according to the } \\
\text { joint evaluation of individual } \\
\text { symptom scores. } \\
\text { Significantly superior efficacy } \\
\text { than placebo in improving the } \\
\text { morning and evening TNSS. } \\
\text { Significantly greater decrease in } \\
\text { morning individual symptoms for } \\
\text { nasal discharge, nasal itching, and } \\
\text { sneezing and itching of ears, } \\
\text { throat, and palate. } \\
\text { Significant improvement in the } \\
\text { evening individual symptoms for } \\
\text { nasal discharge, sneezing, eye } \\
\text { redness, and itching in ears, } \\
\text { throat, and palate. } \\
\text { Significant improvement in the } \\
\text { nasal symptom domain of the } \\
\text { QoL assessment. } \\
\text { Significantly greater expiratory } \\
\text { airflow, but non-significant } \\
\text { increase in the nasal airflow at the } \\
\text { ascending inspiratory phase. } \\
\text { Significantly larger increase in the } \\
\text { total inspiratory nasal airway } \\
\text { resistance in the placebo group } \\
\text { compared with desloratadine } \\
\text { treatment. } \\
\text { Similar AE profile to placebo. }\end{array}$ \\
\hline $\begin{array}{l}\text { Meltzer et } \\
\text { al/ } 2001\end{array}$ & $\begin{array}{l}\text { Two } \\
\text { multicentre, } \\
\text { randomised, } \\
\text { double-blind, } \\
\text { placebo- } \\
\text { controlled, } \\
\text { parallel-group } \\
\text { investigations }\end{array}$ & $\begin{array}{l}\geq 12 \text { years old, } \geq 2- \\
\text { year history of SAR, } \\
\text { positive (prick or } \\
\text { intradermal) skin test } \\
\text { to seasonal allergens } \\
\text { within the past } 12 \\
\text { months, clinically } \\
\text { symptomatic (score } \geq \\
\text { 2), TNSS } \geq 6, \\
\text { TNNSS } \geq 5 \text {, general } \\
\text { good health and being } \\
\text { free of significant } \\
\text { disease }\end{array}$ & $\begin{array}{l}346 \text { in } \\
\text { spring } \\
328 \text { in } \\
\text { autumn }\end{array}$ & $\begin{array}{l}\text { Desloratadine } \\
5 \mathrm{mg} \text { once } \\
\text { daily } \\
\text { Placebo } \\
\text { (For two } \\
\text { weeks) }\end{array}$ & $\begin{array}{l}\text { Significant improvement with } \\
\text { desloratadine treatment in TSS in } \\
\text { both seasons. } \\
\text { Significant reduction in both } \\
\text { nasal and non-nasal symptoms } \\
\text { from the baseline in both seasons } \\
\text { with desloratadine. } \\
\text { No clinically significant } \\
\text { differences compared with } \\
\text { placebo in sedation AE or ECG } \\
\text { data. }\end{array}$ \\
\hline
\end{tabular}




\begin{tabular}{|c|c|c|c|c|c|}
\hline $\begin{array}{l}\text { Authors/ } \\
\text { year }\end{array}$ & Methodology & Inclusion criteria & $\begin{array}{l}\text { No. of } \\
\text { patients }\end{array}$ & $\begin{array}{l}\text { Comparator } \\
\text { regimen }(\mathrm{s})\end{array}$ & Outcomes and results \\
\hline $\begin{array}{l}\text { Bousquet } \\
\text { et al./2009 }\end{array}$ & $\begin{array}{l}\text { Multi-center, } \\
\text { multinational, } \\
\text { randomized, } \\
\text { double-blind, } \\
\text { placebo- } \\
\text { controlled, } \\
\text { parallel-group } \\
\text { Phase IV study }\end{array}$ & $\begin{array}{l}\geq 12 \text { years old; } \geq 2- \\
\text { year history of IAR; } \\
\text { moderate/severe } \\
\text { symptoms; the } \\
\text { reflective total } 5 \\
\text { symptom score } \\
\text { (T5SS) } \geq 6 \text {; the sum } \\
\text { of the daily averages } \\
\text { of the morning plus } \\
\text { evening T5SS for } 4 \\
\text { days and the morning } \\
\text { reflective T5SS on the } \\
\text { morning of the } \\
\text { randomization } \geq 30 ; \\
\text { positive skin prick } \\
\text { tests to common } \\
\text { specified } \\
\text { aeroallergens, no } \\
\text { medications for AR } \\
\text { treatment in the past } \\
14 \text { days }\end{array}$ & 547 & $\begin{array}{l}\text { Desloratadine } \\
\text { 5mg once } \\
\text { daily } \\
\text { Placebo } \\
\text { (For up to } 14 \\
\text { days) }\end{array}$ & $\begin{array}{l}\text { Significant improvement in all } \\
\text { nasal individual symptoms. } \\
\text { Significant reduction in the } \\
\text { morning/evening reflective TSS } \\
\text { and instantaneous symptom } \\
\text { scores than placebo. } \\
\text { Greater improvement in QoL } \\
\text { scores with desloratadine therapy. } \\
\text { Significant reduction in patient- } \\
\text { rated subjective symptom severity } \\
\text { using a visual analogue scale. }\end{array}$ \\
\hline $\begin{array}{l}\text { Demoly et } \\
\text { al./ } 2009\end{array}$ & $\begin{array}{l}\text { Double-blind, } \\
\text { placebo- } \\
\text { controlled, } \\
\text { randomized, } \\
\text { parallel-group } \\
\text { study }\end{array}$ & $\begin{array}{l}\geq 18 \text { years old, } \geq 2- \\
\text { year history of AR } \\
\text { during the cypress } \\
\text { pollen season; } \\
\text { clinically } \\
\text { symptomatic with } \\
\text { cypress pollen AR at } \\
\text { baseline; TNSS plus } \\
\text { TNNSS } 8, \text { nasal } \\
\text { congestion score } 2 ; \\
\text { positive skin prick test } \\
\text { within } 24 \text { months of } \\
\text { the screening visit; } \\
\text { using a medically } \\
\text { acceptable birth } \\
\text { control method; a } \\
\text { negative urine } \\
\text { pregnancy test result } \\
\text { at baseline } \\
\end{array}$ & 233 & $\begin{array}{l}\text { Desloratadine } \\
5 \text { mg daily } \\
\text { Placebo } \\
\text { (For } 15 \text { days) }\end{array}$ & $\begin{array}{l}\text { Desloratadine more effective than } \\
\text { placebo in improving the TSS and } \\
\text { TNSS. } \\
\text { Significant improvement with } \\
\text { desloratadine treatment in QoL } \\
\text { scores and the global response to } \\
\text { therapy. } \\
\text { Numerical but non-significant } \\
\text { improvement in the mean nasal } \\
\text { inspiratory flow scores with } \\
\text { desloratadine treatment }\end{array}$ \\
\hline $\begin{array}{l}\text { Adham/ } \\
2011\end{array}$ & $\begin{array}{l}\text { Open-label, } \\
\text { noninterventio } \\
\text { nal, practice- } \\
\text { based study }\end{array}$ & $\begin{array}{l}\geq 12 \text { years old; } 2 \text {-year } \\
\text { history of SAR or } \\
\text { PAR confirmed with } \\
\text { skin prick test; TSS } 8 ; \\
\text { nasal congestion score } \\
2 ; \text { ocular symptom } \\
\text { score } 2\end{array}$ & 602 & $\begin{array}{l}\text { Desloratadine } \\
5 \text { mg once } \\
\text { daily } \\
\text { Baseline } \\
\text { (For } 2 \text { weeks) }\end{array}$ & 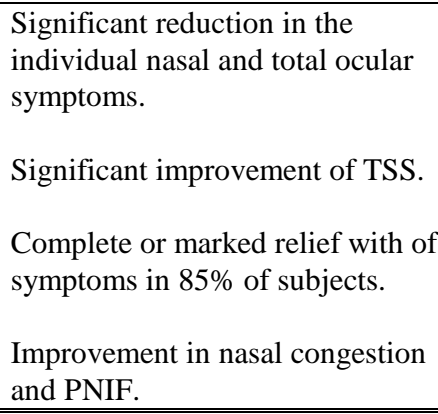 \\
\hline
\end{tabular}




\begin{tabular}{|c|c|c|c|c|c|}
\hline $\begin{array}{l}\text { Authors/ } \\
\text { year }\end{array}$ & Methodology & Inclusion criteria & $\begin{array}{l}\text { No. of } \\
\text { patients }\end{array}$ & $\begin{array}{l}\text { Comparator } \\
\text { regimen }(\mathrm{s})\end{array}$ & Putcomes and results \\
\hline $\begin{array}{l}\text { Lukat et } \\
\text { al./ } 2013\end{array}$ & $\begin{array}{l}\text { Randomized, } \\
\text { double-blind, } \\
\text { placebo- } \\
\text { controlled } \\
\text { study }\end{array}$ & $\begin{array}{l}\geq 12 \text { years old; history } \\
\text { of SAR } \geq 2 \text { years; } \\
\text { positive prick test on } \\
\text { the day or within a } \\
\text { year of screening } \\
\text { visit; } \\
\text { clinically } \\
\text { symptomatic at } \\
\text { screening (NSS } \geq 6, \\
\text { NNSS } \geq 3 \text {, and } \\
\text { rhinorrhea score } \geq 2 \text { ); } \\
\text { normal } \\
\text { electrocardiography } \\
\text { and QTc interval } \\
\text { values }\end{array}$ & 356 & $\begin{array}{l}\text { Desloratadine } \\
5 \mathrm{mg} / \text { daily } \\
\text { Rupatadine } 10 \\
\mathrm{mg} / \text { daily } \\
\text { Placebo }\end{array}$ & $\begin{array}{l}\begin{array}{l}\text { Significant reduction in TSS by } \\
\text { desloratadine and rupatadine } \\
\text { compared to placebo. }\end{array} \\
\text { Superior efficacy of both } \\
\text { desloratadine and rupatadine in } \\
\text { improving nasal and non-nasal } \\
\text { symptoms than placebo. } \\
\text { No statistically significant } \\
\text { differences between rupatadine } \\
\text { and desloratadine in reducing the } \\
\text { baseline symptoms. }\end{array}$ \\
\hline $\begin{array}{l}\text { Berger et } \\
\text { al./ } 2006\end{array}$ & $\begin{array}{l}\text { Randomized, } \\
\text { multi-center, } \\
\text { double-blind, } \\
\text { double-dummy, } \\
\text { active- and } \\
\text { placebo- } \\
\text { controlled }\end{array}$ & $\begin{array}{l}\geq 12 \text { years old; } \geq 2- \\
\text { year history of SAR } \\
\text { during study season; } \\
\text { positive skin test to } \\
\text { prevalent pollen } \\
\text { aeroallergen; morning } \\
\text { instantaneous TSS } \geq \\
6 \text {; free of clinically } \\
\text { significant medical } \\
\text { condition }\end{array}$ & 722 & $\begin{array}{l}\text { Desloratadine } \\
5 \mathrm{mg} / \text { day } \\
\text { Fexofenadine } \\
180 \mathrm{mg} / \text { day } \\
\text { Placebo }\end{array}$ & $\begin{array}{l}\text { Superior efficacy of both } \\
\text { desloratadine and fexofenadine in } \\
\text { morning instantaneous TSS and } \\
\text { morning/evening reflective TSS } \\
\text { than placebo but comparative } \\
\text { efficacy between two active } \\
\text { treatments. } \\
\text { Both active treatments associated } \\
\text { with significant improvements in } \\
\text { morning instantaneous individual } \\
\text { symptoms (sneezing and itchy } \\
\text { nose, throat, and palate). } \\
\text { Desloratadine more advantageous } \\
\text { than fexofenadine in alleviating } \\
\text { ocular symptoms (itchy, watery, } \\
\text { and red eyes). } \\
\text { Superior efficacy of both active } \\
\text { treatments in morning/evening } \\
\text { reflective scores by reducing the } \\
\text { symptoms of sneezing, itchy nose, } \\
\text { throat, palate, ocular symptoms, } \\
\text { and nasal congestion. } \\
\text { Significant reduction of the } \\
\text { severity score of rhinorrhoea with } \\
\text { desloratadine compared to } \\
\text { fexofenadine. } \\
\text { A positive trend in improvement } \\
\text { of symptom severity through the } \\
\text { subjective assessment by } \\
\text { investigators and subjects during } \\
\text { the entire study. } \\
\text { Relatively more incidence of AEs } \\
\text { with fexofenadine followed by } \\
\text { placebo and desloratadine }\end{array}$ \\
\hline
\end{tabular}




\begin{tabular}{|c|c|c|c|c|c|}
\hline $\begin{array}{l}\text { Authors/ } \\
\text { year }\end{array}$ & Methodology & Inclusion criteria & $\begin{array}{l}\text { No. of } \\
\text { patients }\end{array}$ & $\begin{array}{l}\text { Comparator } \\
\text { regimen(s) }\end{array}$ & Outcomes and results \\
\hline $\begin{array}{l}\text { Raphael et } \\
\text { al./ } 2005\end{array}$ & $\begin{array}{l}\text { Multi-center, } \\
\text { parallel-group, } \\
\text { randomized, } \\
\text { double-blind, } \\
\text { double-dummy, } \\
\text { placebo- } \\
\text { controlled } \\
\text { study }\end{array}$ & $\begin{array}{l}12 \text { to } 65 \text { years old; at } \\
\text { least moderate SAR } \\
\text { due to autumn weed } \\
\text { pollen; positive skin } \\
\text { prick or intradermal } \\
\text { test reaction in the } \\
\text { past year; a minimum } \\
\text { moderate/moderately } \\
\text { severe baseline } \\
\text { symptoms of SAR }\end{array}$ & 610 & $\begin{array}{l}\text { Desloratadine } \\
5 \text { mg daily } \\
\text { Diphenhydra } \\
\text { mine } 50 \mathrm{mg} \\
\text { three time } \\
\text { daily } \\
\text { Placebo }\end{array}$ & $\begin{array}{l}\text { Statistically and clinically } \\
\text { significant improvements in TSS } \\
\text { and TNSS with diphenhydramine } \\
\text { compared with either placebo or } \\
\text { desloratadine. } \\
\text { Significant superiority of } \\
\text { diphenhydramine in improving all } \\
\text { individual SAR symptom scores, } \\
\text { while desloratadine only } \\
\text { significantly effective on sneezing } \\
\text { scores. } \\
\text { Diphenhydramine more effective } \\
\text { than desloratadine in treating } \\
\text { nasal congestion. } \\
\text { Higher incidence of AEs and } \\
\text { somnolence with } \\
\text { diphenhydramine. }\end{array}$ \\
\hline $\begin{array}{l}\text { Bachert } \\
\text { and } \\
\text { Maurer/ } \\
2010\end{array}$ & $\begin{array}{l}\text { Four } \\
\text { prospective } \\
\text { post-marketing } \\
\text { surveillance } \\
\text { studies }\end{array}$ & $\begin{array}{l}\geq 12 \text { years old; SAR } \\
\text { or chronic idiopathic } \\
\text { urticaria }\end{array}$ & $\begin{array}{l}\text { Overall, } \\
77,880 \\
\text { subjects } \\
\text { with } \\
47,953+ \\
5,399 \\
\text { having } \\
\text { SAR }\end{array}$ & $\begin{array}{l}\text { Desloratadine } \\
5 \text { mg once } \\
\text { daily (mean } \\
\text { duration of } 40 \\
\text { days) } \\
\text { compared to } \\
\text { baseline } \\
\text { A post hoc } \\
\text { analysis in the } \\
\text { subgroup of } \\
\text { people } \\
\text { previously } \\
\text { treated with } \\
\text { another } \\
\text { second- } \\
\text { generation } \\
\text { antihistamine }\end{array}$ & $\begin{array}{l}\text { Significant reduction in TSS and } \\
\text { individual symptom scores } \\
\text { (including nasal, ocular, dermal, } \\
\text { and asthma symptom scores) from } \\
\text { the baseline after desloratadine } \\
\text { therapy. } \\
\text { Significant reduction in the mean } \\
\text { nasal sum scores compared to } \\
\text { baseline. } \\
\text { Significant reduction in the } \\
\text { percentage of subjects reporting } \\
\text { moderate and severe symptoms } \\
\text { and nasal congestion after } \\
\text { desloratadine treatment. } \\
\text { Significant reduction in severity } \\
\text { of sleep impairment and daily } \\
\text { activity impairment associated } \\
\text { with SAR. } \\
\text { Higher subjective efficacy of } \\
\text { desloratadine than cetirizine, } \\
\text { loratadine, fexofenadine, and } \\
\text { mizolastine in comparative } \\
\text { assessment of desloratadine } \\
\text { compared with previous } \\
\text { antihistamine monotherapy. } \\
\text { Fatigue, headache, and dry mouth } \\
\text { the most commonly reported } \\
\text { desloratadine-related AEs. }\end{array}$ \\
\hline
\end{tabular}




\begin{tabular}{|c|c|c|c|c|c|}
\hline $\begin{array}{l}\text { Authors/ } \\
\text { year }\end{array}$ & Methodology & Inclusion criteria & $\begin{array}{l}\text { No. of } \\
\text { patients }\end{array}$ & $\begin{array}{l}\text { Comparator } \\
\text { regimen }(\mathrm{s})\end{array}$ & Outcomes and results \\
\hline $\begin{array}{l}\text { Deruaz et } \\
\text { al/ } 2003\end{array}$ & $\begin{array}{l}\text { Double-blind, } \\
\text { placebo- } \\
\text { controlled, } \\
\text { crossover study }\end{array}$ & $\begin{array}{l}18 \text { - } 60 \text { years old; } \\
\text { positive history of AR } \\
\text { during the latest } \\
\text { pollen season; nasal } \\
\text { reaction threshold } \leq \\
10,000 \text { standardized } \\
\text { quality units/mL grass } \\
\text { pollen at screening }\end{array}$ & 24 & 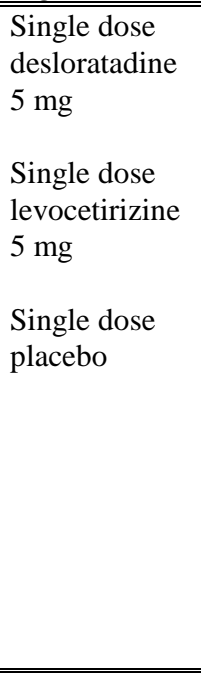 & 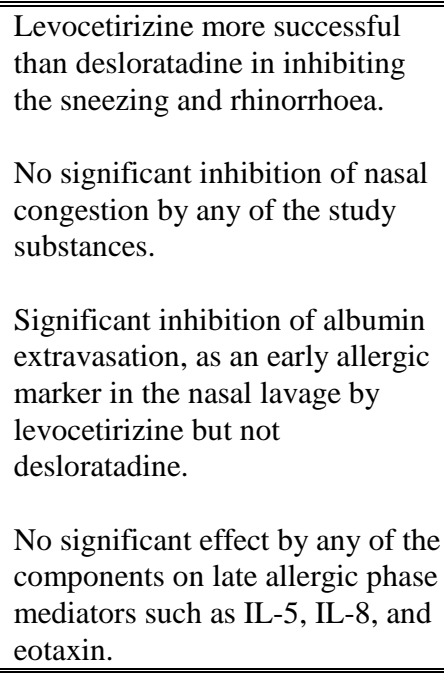 \\
\hline $\begin{array}{l}\text { Day et al./ } \\
2004\end{array}$ & $\begin{array}{l}\text { Randomised, } \\
\text { double-blind, } \\
\text { placebo- } \\
\text { controlled, } \\
\text { parallel-group } \\
\text { study }\end{array}$ & $\begin{array}{l}\geq 16 \text { years old, a } \\
\text { documented history of } \\
\text { ragweed-induced } \\
\text { allergic rhinitis for the } \\
\text { past two consecutive } \\
\text { seasons, a positive } \\
\text { skin prick test to } \\
\text { ragweed the year prior } \\
\text { to study }\end{array}$ & $\begin{array}{l}373 \\
\text { patients } \\
\text { with } \\
\text { ragweed } \\
\text { induced } \\
\text { RA }\end{array}$ & $\begin{array}{l}\text { Desloratadine } \\
5 \mathrm{mg} / \text { day } \\
\text { Levocetirizine } \\
5 \mathrm{mg} / \text { day } \\
\text { Placebo }\end{array}$ & $\begin{array}{l}\text { Both active treatments superior to } \\
\text { placebo in improving major } \\
\text { symptom complex score. } \\
\text { Significantly greater symptom } \\
\text { improvement with levocetirizine } \\
\text { compared to desloratadine. } \\
\text { Faster action with levocetirizine } \\
\text { compared to desloratadine. } \\
\text { Resolution of nasal congestion to } \\
\text { a greater extent with } \\
\text { levocetirizine than desloratadine. } \\
\text { Patient satisfaction with symptom } \\
\text { improvement significantly higher } \\
\text { with both active medications } \\
\text { compared to placebo. }\end{array}$ \\
\hline $\begin{array}{l}\text { Bhatia et } \\
\text { al/ } 2005\end{array}$ & $\begin{array}{l}\text { Randomized, } \\
\text { double-blind, } \\
\text { double-dummy, } \\
\text { parallel study }\end{array}$ & $\begin{array}{l}\text { Age } 18 \text { to } 45 \text { years } \\
\text { old, a history of } \\
\text { allergy to tree or grass } \\
\text { pollens, positive skin } \\
\text { test to tree or grass } \\
\text { allergens, } \\
\text { symptomatic during } \\
\text { the spring season for } \\
\text { the past } 2 \text { years }\end{array}$ & 61 & $\begin{array}{l}\begin{array}{l}\text { Oral } \\
\text { desloratadine, } \\
5 \mathrm{mg} / \text { day }\end{array} \\
\text { Nasal } \\
\text { budesonide, } \\
32 \mu \mathrm{g} / \mathrm{d} \text { per } \\
\text { nostril } \\
\text { Placebo } \\
\text { (All for two } \\
\text { weeks) }\end{array}$ & $\begin{array}{l}\text { Superior efficacy of nasal } \\
\text { budesonide compared to } \\
\text { desloratadine in improving the } \\
\text { overall NPIF }{ }^{*} \text { values and } \\
\text { increasing nasal flow. } \\
\text { Significant improvement in the } \\
\text { RQLQ with both treatments with } \\
\text { no differences between } \\
\text { treatments. } \\
\text { Significant decrease in the } \\
\text { symptom scores with both } \\
\text { medications, no significant } \\
\text { differences between treatments. }\end{array}$ \\
\hline
\end{tabular}




\begin{tabular}{|c|c|c|c|c|c|}
\hline $\begin{array}{l}\text { Authors/ } \\
\text { year }\end{array}$ & Methodology & Inclusion criteria & $\begin{array}{l}\text { No. of } \\
\text { patients }\end{array}$ & $\begin{array}{l}\text { Comparator } \\
\text { regimen(s) }\end{array}$ & Outcomes and results \\
\hline $\begin{array}{l}\text { Crampton/ } \\
2003\end{array}$ & $\begin{array}{l}\text { Randomized, } \\
\text { double-masked, } \\
\text { placebo- and } \\
\text { active } \\
\text { controlled, } \\
\text { single-centre } \\
\text { clinical trial }\end{array}$ & $\begin{array}{l}\text { Age } \geq 18 \text { years old; } \\
\text { history of rhino- } \\
\text { conjunctivitis; able to } \\
\text { follow study } \\
\text { instructions; willing } \\
\text { to avoid disallowed } \\
\text { medications }\end{array}$ & 80 & $\begin{array}{l}\begin{array}{l}\text { Ketotifen } \\
\text { ophthalmic } \\
\text { solution } \\
0.025 \%+ \\
\text { placebo tablet }\end{array} \\
\text { Desloratadine } \\
5 \text { mg tablet + } \\
\text { placebo } \\
\text { eyedrop } \\
\text { Ketotifen } \\
0.025 \% \\
\text { ophthalmic } \\
\text { solution + } \\
\text { desloratadine } \\
5 \text { mg tablet }\end{array}$ & $\begin{array}{l}\text { Significantly lower ocular itching } \\
\text { scores in ketotifen or } \\
\text { ketotifen/desloratadine } \\
\text { combination group compared to } \\
\text { the desloratadine group alone. } \\
\text { Significantly less ocular redness } \\
\text { with ketotifen therapy alone } \\
\text { compared with desloratadine and } \\
\text { ketotifen/desloratadine } \\
\text { combination at } 15 \text { and } 20 \text { minutes } \\
\text { after allergen induction. } \\
\text { No statistically significant } \\
\text { efficacy on nasal symptoms } \\
\text { between treatments except } \\
\text { ketotifen/loratadine combination } \\
\text { at } 50 \text { minutes timepoint after the } \\
\text { conjunctival allergen challenge. } \\
\text { Less tearing with desloratadine } \\
\text { treatment compared with other } \\
\text { groups (non-significant). }\end{array}$ \\
\hline $\begin{array}{l}\text { Bachert et } \\
\text { al./ } 2009\end{array}$ & $\begin{array}{l}\text { Randomized, } \\
\text { double-blind, } \\
\text { placebo- } \\
\text { controlled, } \\
\text { parallel-group } \\
\text { multicentre } \\
\text { study }\end{array}$ & $\begin{array}{l}\text { Age } 12-70 \text { years old; } \\
\text { history of SAR } \geq 2 \\
\text { years; positive skin } \\
\text { prick test to at least } \\
\text { one seasonal allergen, } \\
\text { positive prick test to } \\
\text { perennial allergens } \\
\text { but no symptoms of } \\
\text { PAR; minimum } \\
\text { reflective nasal } \\
\text { symptom score of } \geq \\
36\end{array}$ & 720 & $\begin{array}{l}\text { Bilastine } 10 \\
\text { mg once daily } \\
\text { Desloratadine } \\
5 \mathrm{mg} \text { once } \\
\text { daily } \\
\text { Placebo }\end{array}$ & $\begin{array}{l}\text { Significant improvement in TSS, } \\
\text { NSS, and NNSS with both } \\
\text { treatments compared to placebo. } \\
\text { Both treatments comparable in } \\
\text { efficacy. } \\
\text { Both treatments equally effective } \\
\text { in increasing the RQLQ QoL } \\
\text { measures than placebo. } \\
\text { Significant efficacy on individual } \\
\text { QoL domains except for nasal } \\
\text { symptoms, emotional, and sleep } \\
\text { components by bilastine, and } \\
\text { nasal symptoms and emotional } \\
\text { components by desloratadine. }\end{array}$ \\
\hline
\end{tabular}

\section{Asthma}

\section{Desloratadine vs. Placebo}

The anti-inflammatory action of desloratadine was put in test on reducing the systemic inflammation as well as nasal and bronchial inflammation in patients with asthma accompanied with grass pollen-induced $\mathrm{AR}^{25}$. Twenty-six patients received either desloratadine or placebo for seven days and then underwent a nasal provocation test by exposing them to grass pollen allergens. Compared to the placebo, desloratadine therapy resulted in a substantial increase in the PNIF before the nasal provocation test. Also, desloratadine significantly reduced the number of circulating eosinophils in allergic inflammation ${ }^{25}$. However, such reduction was not reflected in the eosinophils in nasal mucosa. Bronchial parameters, as demonstrated by the reactions to the methacholine provocation test, did not significantly change with desloratadine treatment. In this study, desloratadine did not show an improvement in the forced expiratory volume (FEV1) values and had limited efficacy in improving the nasal symptoms and PNIF after the nasal provocation $^{25}$.

Another RCT evaluated the effect of $5 \mathrm{mg}$ desloratadine on a group of 20 patients with $\mathrm{AR}$ and exercise-induced bronchoconstriction where patients underwent an exercise challenge test before and seven days after receiving desloratadine or placebo ${ }^{26}$. Although desloratadine treatment resulted in a significantly less drop in the FEV1 compared to the baseline visits, no statistical difference was observed in this regard between 
desloratadine and placebo ${ }^{26}$. Moreover, the area under the curve for percentage fall in FEV1 did not change significantly between the treatment and placebo group ${ }^{26}$.

Among patients with seasonal allergic asthma and SAR desloratadine $5 \mathrm{mg}$ led to a significant reduction in the morning/evening $\mathrm{TSS}^{27}$. Regarding the asthma-specific outcomes, desloratadine demonstrated superior effectiveness in reducing asthma symptom scores in patients with simultaneous SAR and asthma, individual asthma symptoms such as wheezing, cough, breathlessness, and chest tightness as well as controlling the lower airway symptoms/inflammation and bronchial hyper-responsiveness parameters, and the frequency of beta-agonist inhaler use $\mathrm{e}^{10 \& 27}$. In a subgroup analysis, among patients with concomitant SAR and asthma, the reduction in the mean reflective nasal congestion scores was significantly greater than placebo ${ }^{13}$.

Another evaluation of 69 patients with SAR and concomitant seasonal asthma assessed the effect of treatment with desloratadine $5 \mathrm{mg}$ on inflammatory mediators $^{28}$. Improvements in rhinitis and nasal congestion was in favor of desloratadine treatment in this evaluation. However, desloratadine did not significantly affect the levels of cytokines, including IL-4, IL-10, IL18, and TGF-beta failing to support the evidence around anti-inflammatory properties of this medication ${ }^{28}$.

In another study, children with AR using either regular or on-demand desloratadine used an equal number of decongestant tablets or anti-allergic eye drops. Interestingly, after a 4week treatment, patients using desloratadine on a regular basis had a significantly lower average salbutamol puffer use than those taking it on-demand. This was in line with the findings of Bachert et al. ${ }^{10}$ in which more than half of the cases reduced asthma medication use during the desloratadine treatment period.

\section{Desloratadine vs. Other Treatment Agents}

In one study, the patients were randomly treated either with oral desloratadine $5 \mathrm{mg}$, montelukast $10 \mathrm{mg}$, or placebo over a 4-week period. Both treatments achieved significant reductions in instantaneous total asthma symptom scores (TASS) the morning after the first dose as well as significant reductions in morning/evening reflective TASS scores. In terms of the individual asthma symptoms, including coughing, wheezing, and difficulty breathing, both medications were significantly superior to placebo from day 2 of the treatment and throughout the 4-week period ${ }^{29}$. Through an exploratory analysis, this study found that desloratadine achieved a greater 1 to 2 -week impact in reducing the TASS in patients with severe asthma symptoms when compared with those with milder asthma. Looking at the pulmonary function test evaluations, both medications resulted in significant but comparable improvements in FEV1. Both desloratadine and montelukast were able to significantly decrease the frequency of beta2 agonist use in patients without a superiority of one to another.

\section{Perennial or Persistent Allergic Rhinitis}

Perennial or persistent allergic rhinitis refers to the allergic conditions where symptoms do not subside throughout the year. The ARIA guidelines describe persistent allergic rhinitis (PAR) when the symptoms persist more than 4 days/week and for more than 4 consecutive weeks ${ }^{30}$. The following section summarizes the current evidence around the efficacy of desloratadine on this class of allergic conditions.

\section{Desloratadine vs. Placebo}

Desloratadine has been significantly more effective than placebo in reducing the morning and evening nasal congestion scores and the RQLQ measures among patients with PAR as shown in a four-week trial ${ }^{31}$. Such significant improvements commenced as early as day 3 and the efficacy was sustained consistently from day 8 to the end of the study.

In another four-week trial among 1,179 patients with PAR, desloratadine demonstrated superior efficacy to placebo in reducing the morning/evening reflective TSS at all times ${ }^{32}$. Similar efficacy was demonstrated in another RCT between 676 and 716 patients with PAR. Desloratadine treatment was successful in significantly diminishing the morning and evening instantaneous and reflective TSS as demonstrated by a number of studies ${ }^{32-34}$. Regarding the individual symptoms, desloratadine has shown significant reduction in the TNSS and TNNSS in patients with 
$\mathrm{PAR}^{32-34}$. Improvements in the PNIF from the baseline have also been significant in favour of the desloratadine treatment group. A prospective, open-label non-random study of 47 patients with PAR treated with desloratadine $5 \mathrm{mg}$ daily showed a significant reduction in the median rhinitis symptoms relative to the baseline measurements ${ }^{35}$. Sneezing, rhinorrhoea, and palatal itchiness were the symptoms which were resolved significantly while the changes in nasal obstruction or ocular and nasal itching were not considered statistically significant. The median endoscopic appearance score, which assessed the nasal cavity from the aspects of nasal polyps, nasal discharge, nasal oedema, and septal deviation, also significantly dropped after desloratadine treatment ${ }^{35}$.

In concordance with previous reports, desloratadine also demonstrated superior efficacy to placebo in improving the individual domains of the QoL measures ${ }^{31 \& 33 \& 35}$. Individual components of RQLQ QoL, including nasal symptoms, specific activities, general problems, practical problems, sleep problems, and emotional functioning except ocular symptoms have also shown to improve with desloratadine ${ }^{31}$. Another study used the
Medical Outcomes Study 36-item short form health survey to assess the health-related QoL a tool different from the commonly mused RQLQ tool used by previous studies ${ }^{35}$. Of the eight different scales, only the general health perception was found to be statistically improved after treatment, while improvement in social functions was marginal ${ }^{35}$.

Paediatric populations with PAR have also been studied for the effectiveness of desloratadine. An open-label observational multi-centre study conducted in a paediatric population from five Latin American countries reported the efficacy of desloratadine in a mixed diagnosis of SAR and PAR, though PAR patients were in the majority $(61 \% \text { vs } 39 \%)^{36}$. Desloratadine $2.5 \mathrm{mg} /$ day for 6 weeks was associated with a significant reduction in the mean TSS as well as all individual symptom scores including nasal congestion. The efficacy of desloratadine monotherapy was found to be comparable with desloratadine plus corticosteroid treatment in this study [36]. There are other studies in the literature which have studied the efficacy of desloratadine as fixed-dose combination products with secondary agents (Table 2$)^{37}$.

Table 2: An overview of the research studies on clinical efficacy of desloratadine either compared to placebo, baseline measures, or other treatment agents in treatment of perennial or persistent allergic rhinitis

\begin{tabular}{|c|c|c|c|c|c|}
\hline Authors & methodology & Inclusion criteria & $\begin{array}{l}\text { No. of } \\
\text { patient } \\
\text { s }\end{array}$ & Comparator regimens & Outcomes and results \\
\hline $\begin{array}{l}\text { Holmberg } \\
\text { et al./ } \\
2009\end{array}$ & $\begin{array}{l}\text { Randomized, } \\
\text { double-blind, } \\
\text { placebo- } \\
\text { controlled } \\
\text { trial }\end{array}$ & $\begin{array}{l}\text { 18-65 years old, } \\
\text { positive skin prick } \\
\text { test or radio- } \\
\text { allergosorbent test } \\
\text { class } \geq 2 \text { to house } \\
\text { dust mite or cat } \\
\text { dander within } 24 \\
\text { months prior to } \\
\text { screening, } \geq 2 \text {-year } \\
\text { history of } \\
\text { moderate/severe } \\
\text { nasal symptoms, } \\
\text { moderate/severe } \\
\text { nasal congestion } \\
\text { score } \geq 4 \text { of } 6 \text { rated } \\
\text { on a } 7 \text {-point scale for } \\
\geq 4 / 7 \text { days during the } \\
\text { screening }\end{array}$ & 584 & $\begin{array}{l}\text { Desloratadine } 5 \mathrm{mg} / \text { daily } \\
\text { Placebo }\end{array}$ & $\begin{array}{l}\text { Significant efficacy of } \\
\text { desloratadine than placebo } \\
\text { in reducing the morning and } \\
\text { evening nasal congestion } \\
\text { scores. } \\
\text { Significant improvement in } \\
\text { QoL measures. } \\
\text { Superior efficacy of } \\
\text { desloratadine in improving } \\
\text { the individual domains of } \\
\text { QoL measures except ocular } \\
\text { symptoms. } \\
\text { Significant relief in } \\
\text { rhinorrhoea and nasal } \\
\text { congestion with } \\
\text { desloratadine but no } \\
\text { significant effect on minor } \\
\text { nasal symptoms such as } \\
\text { sneezing and itching. }\end{array}$ \\
\hline
\end{tabular}




\begin{tabular}{|c|c|c|c|c|c|}
\hline Authors & " methodology & Inclusion criteria & $\begin{array}{l}\text { No. of } \\
\text { patient } \\
\text { s }\end{array}$ & Comparator regimens & Outcomes and results \\
\hline $\begin{array}{l}\text { Kim et } \\
\text { al./2006 }\end{array}$ & $\begin{array}{l}\text { Randomized, } \\
\text { double-blind, } \\
\text { placebo- } \\
\text { controlled, } \\
\text { multicenter } \\
\text { study }\end{array}$ & $\begin{array}{l}12 \text { years old; } \\
\text { history of PAR } \geq 2 \\
\text { years; baseline TSS } \geq \\
9, \text { TNSS } \geq 5, \text { TNNSS } \\
\geq 4 ; \text { positive skin } \\
\text { prick response to an } \\
\text { appropriate perennial } \\
\text { allergen within } 12 \\
\text { months; significant } \\
\text { disease-free; negative } \\
\text { serum pregnancy } \\
\text { test; using an } \\
\text { appropriate birth- } \\
\text { control method }\end{array}$ & 101,179 & $\begin{array}{l}\text { Desloratadine } 5 \mathrm{mg} / \text { daily } \\
\text { Placebo } \\
\text { (For } 4 \text { weeks) }\end{array}$ & $\begin{array}{l}\text { Superior efficacy of } \\
\text { desloratadine to placebo in } \\
\text { reducing the } \\
\text { morning/evening reflective } \\
\text { TSS, TNSS, and TNNSS. } \\
\text { Significant improvements in } \\
\text { the PNIF from the baseline } \\
\text { in favour of the } \\
\text { desloratadine treatment } \\
\text { group (better improvement } \\
\text { in morning PNIF). } \\
\text { Similar AEs profile between } \\
\text { desloratadine and placebo. }\end{array}$ \\
\hline $\begin{array}{l}\text { Cingi et } \\
\text { al./ } 2013\end{array}$ & $\begin{array}{l}\text { Prospective } \\
\text { and multi- } \\
\text { centric, } \\
\text { placebo- } \\
\text { controlled } \\
\text { clinical trial }\end{array}$ & $\begin{array}{l}20-51 \text { years old; } \\
\text { diagnosis of PAR as } \\
\text { per ARIA criteria for } \\
\geq 2 \text { years; general } \\
\text { good health; non- } \\
\text { smoker }\end{array}$ & 40 & $\begin{array}{l}\text { Desloratadine/montelukast } \\
5 / 10 \text { mg fixed dose } \\
\text { combination } \\
\text { Placebo } \\
\text { (For three months) }\end{array}$ & $\begin{array}{l}\text { Decreased nasal allergy } \\
\text { symptoms including itching, } \\
\text { sneezing, discharge, and } \\
\text { congestion. } \\
\text { Increased minimum-cross } \\
\text { sectional area and volume } \\
\text { indicating a beneficial effect } \\
\text { of treatment on nasal } \\
\text { obstruction. } \\
\text { Significant improvement } \\
\text { than placebo on the RQLQ } \\
\text { QoL scores and all domains } \\
\text { of the QoL. }\end{array}$ \\
\hline $\begin{array}{l}\text { Simons et } \\
\text { al./ } 2003\end{array}$ & $\begin{array}{l}\text { Randomized, } \\
\text { placebo- } \\
\text { controlled, } \\
\text { double-blind, } \\
\text { parallel- } \\
\text { group study }\end{array}$ & $\begin{array}{l}\geq 12 \text { years old; } \\
\text { history of moderate } \\
\text { PAR } \geq 2 \text { years; } \\
\text { positive skin test } \\
\text { response to } \geq 1 \\
\text { specified allergens } \\
\text { within the previous } \\
\text { year, having PAR } \\
\text { symptoms with a } \\
\text { reflective TSS } \geq 10 \\
\text { and no greater than } \\
\text { moderate nasal } \\
\text { stuffiness/congestion, } \\
\text { the summed } \\
\text { reflective congestion } \\
\text { score } \leq 12 \text { in the } 3 \\
\text { days before baseline, } \\
\text { the summed TSS } \geq \\
60, \text { overall rhinitis } \\
\text { score } \geq 2 \text { at baseline, } \\
\text { good general health; } \\
\text { negative serum } \\
\text { pregnancy test and } \\
\text { use of an accepted } \\
\text { method of } \\
\text { contraception }\end{array}$ & 676 & $\begin{array}{l}\text { Desloratadine } 5 \mathrm{mg} / \text { once } \\
\text { daily } \\
\text { Placebo } \\
\text { (For } 4 \text { weeks) }\end{array}$ & $\begin{array}{l}\text { Superiority of desloratadine } \\
\text { to placebo in significantly } \\
\text { decreasing the PAR } \\
\text { symptoms. } \\
\text { Significant reduction in the } \\
\text { morning/evening } \\
\text { instantaneous and reflective } \\
\text { TSS. } \\
\text { Significant alleviation of } \\
\text { individual symptoms scores } \\
\text { with desloratadine } \\
\text { (significant reduction of the } \\
\text { total non-nasal scores as } \\
\text { well as nasal symptoms } \\
\text { including rhinorrhoea, nasal } \\
\text { itching, sneezing, and } \\
\text { postnasal drip). } \\
\text { Similar occurrence of AEs } \\
\text { between desloratadine and } \\
\text { placebo. }\end{array}$ \\
\hline
\end{tabular}




\begin{tabular}{|c|c|c|c|c|c|}
\hline Authors & methodology & Inclusion criteria & $\begin{array}{l}\text { No. of } \\
\text { patient } \\
\text { s } \\
\end{array}$ & Comparator regimens & Outcomes and results \\
\hline $\begin{array}{l}\text { Bousquet } \\
\text { et al./ } \\
2010\end{array}$ & $\begin{array}{l}\text { Randomized } \\
\text { placebo- } \\
\text { controlled } \\
\text { trial }\end{array}$ & $\begin{array}{l}\geq 12 \text { years old, } \geq 2 \text { - } \\
\text { year history of } \\
\text { ARIA-defined PAR, } \\
\text { moderate/severe } \\
\text { symptoms, reflective } \\
\text { T5SS } \geq 8 \text { at } \\
\text { screening, the sum of } \\
\text { the daily averages of } \\
\text { morning and evening } \\
\text { reflective T5SS in } 4 \\
\text { days and the morning } \\
\text { reflective T5SS on } \\
\text { the morning of } \\
\text { randomization= } 640, \\
\text { positive skin prick } \\
\text { test to common } \\
\text { aeroallergens, no } \\
\text { medication for } \\
\text { allergic rhinitis for } \\
\text { specified periods } \\
\text { (washout) prior to } \\
\text { study }\end{array}$ & 716 & $\begin{array}{l}\begin{array}{l}\text { Desloratadine } 5 \mathrm{mg} \text { once } \\
\text { daily }\end{array} \\
\text { Placebo } \\
\text { (For } 12 \text { weeks) }\end{array}$ & $\begin{array}{l}\text { Significantly greater } \\
\text { reduction with desloratadine } \\
\text { in the morning/evening } \\
\text { reflective TSS relative to the } \\
\text { placebo during the first } \\
\text { month and on each } \\
\text { individual day. } \\
\text { Significant reduction in the } \\
\text { individual nasal symptom } \\
\text { scores with desloratadine } \\
\text { therapy than placebo. } \\
\text { Rapid onset of effect from } \\
\text { the second day and } \\
\text { significant reduction in the } \\
\text { morning instantaneous TSS. } \\
\text { Significant improvement of } \\
\text { QoL measures than placebo. } \\
\text { AEs associated with } \\
\text { desloratadine comparable } \\
\text { with placebo. }\end{array}$ \\
\hline $\begin{array}{l}\text { Lam et al./ } \\
2007\end{array}$ & $\begin{array}{l}\text { Prospective, } \\
\text { open-label, } \\
\text { non-blinded, } \\
\text { non- } \\
\text { randomised } \\
\text { study }\end{array}$ & $\begin{array}{l}>12 \text { years old, } \\
\text { diagnosed with } \\
\text { chronic perennial } \\
\text { rhinitis (symptoms } \geq \\
12 \text { weeks), } \\
\text { colleagues' rhinitis } \\
\text { symptoms score } \geq 2, \\
\text { appropriate washout } \\
\text { period with recent } \\
\text { medications such as } \\
\text { antihistamines and } \\
\text { corticosteroids }\end{array}$ & 47 & $\begin{array}{l}\text { Desloratadine } 5 \mathrm{mg} \text { once } \\
\text { daily for } 12 \text { weeks } \\
\text { Baseline }\end{array}$ & $\begin{array}{l}\text { Significant reduction in the } \\
\text { median rhinitis symptoms } \\
\text { after treatment with } \\
\text { desloratadine. } \\
\text { Significant drop in the } \\
\text { median endoscopic } \\
\text { appearance score after } \\
\text { desloratadine treatment. } \\
\text { Significant relief in } \\
\text { sneezing, rhinorrhoea, and } \\
\text { palatal itchiness but no } \\
\text { significant changes in nasal } \\
\text { obstruction or ocular and } \\
\text { nasal itching. } \\
\text { Significant improvement in } \\
\text { the general health } \\
\text { perception domain of QoL } \\
\text { but non-significant changes } \\
\text { in other domains. }\end{array}$ \\
\hline $\begin{array}{l}\text { Tassinari } \\
\text { et al./ } \\
2009\end{array}$ & $\begin{array}{l}\text { Open-label, } \\
\text { observational } \\
\text {, multicenter } \\
\text { study }\end{array}$ & $\begin{array}{l}6 \text { to } 12 \text { years old; } \\
\text { physician-confirmed } \\
\text { diagnosis of either } \\
\text { SAR or PAR }\end{array}$ & 455 & $\begin{array}{l}\text { Desloratadine syrup } 2.5 \\
\text { mg/day }(5 \mathrm{~mL}) \\
\text { (For } 6 \text { weeks) }\end{array}$ & $\begin{array}{l}\text { Significant reduction in the } \\
\text { mean TSS and all individual } \\
\text { symptom scores including } \\
\text { nasal congestion. } \\
\text { Comparable efficacy of } \\
\text { desloratadine monotherapy } \\
\text { with desloratadine plus } \\
\text { corticosteroid treatment. }\end{array}$ \\
\hline
\end{tabular}




\begin{tabular}{|c|c|c|c|c|c|}
\hline Authors & methodology & Inclusion criteria & $\begin{array}{l}\text { No. of } \\
\text { patient } \\
\text { s }\end{array}$ & Comparator regimens & Outcomes and results \\
\hline $\begin{array}{l}\text { Wandalsen } \\
\text { et al./ } \\
2016\end{array}$ & $\begin{array}{l}\text { Prospective, } \\
\text { multi-center, } \\
\text { double-blind, } \\
\text { randomized, } \\
\text { controlled } \\
\text { study of } \\
\text { parallel group }\end{array}$ & $\begin{array}{l}\text { 2-12 years old, } \\
\text { moderate/severe } \\
\text { PAR, clinical } \\
\text { features consistent } \\
\text { with the PAR } \\
\text { (recurrent nasal } \\
\text { symptoms, and } \\
\text { sensitization to } \\
\text { airborne allergens by } \\
\text { the presence of } \\
\text { specific IgE), nasal } \\
\text { symptoms scores } \geq 6 \\
\text { in the past week }\end{array}$ & 195 & $\begin{array}{l}\text { Desloratadine }(0.5 \\
\mathrm{mg} / \mathrm{mL}) \text { and prednisolone } \\
(4 \mathrm{mg} / \mathrm{mL}) \text { combined in } \\
\text { oral solution } \\
\text { Dexchlorpheniramine } \\
\text { maleate }(0.4 \mathrm{mg} / \mathrm{mL}) \text { and } \\
\text { betamethasone }(0.05 \\
\mathrm{mg} / \mathrm{mL}) \text { syrup }\end{array}$ & $\begin{array}{l}\text { Significant but comparable } \\
\text { reduction in the nasal and } \\
\text { extra-nasal symptom scores } \\
\text { by each compound. } \\
\text { More than } 90 \% \text { of subjects } \\
\text { in both groups reporting to } \\
\text { be better/much better after } \\
\text { treatment. } \\
\text { Somnolence, headache, and } \\
\text { fever significantly higher in } \\
\text { the } \\
\text { dexchlorpheniramine/betam } \\
\text { ethasone group, while } \\
\text { epistaxis significantly } \\
\text { higher with } \\
\text { desloratadine/prednisolone. }\end{array}$ \\
\hline $\begin{array}{l}\text { Lee et al./ } \\
2004\end{array}$ & $\begin{array}{l}\text { Randomized, } \\
\text { double-blind, } \\
\text { placebo- } \\
\text { controlled, } \\
\text { cross-over }\end{array}$ & $\begin{array}{l}\text { History of PAR } \\
\text { without concomitant } \\
\text { asthma, no oral } \\
\text { corticosteroids or } \\
\text { antibiotics over the } \\
\text { past } 3 \text { months, a } \\
\text { positive skin prick } \\
\text { test response to } \\
\text { house dust mite, a } \\
\text { positive response to } \\
\text { nasal AMP challenge } \\
\text { at screening }\end{array}$ & 16 & $\begin{array}{l}\text { Single dose desloratadine } \\
5 \mathrm{mg} \\
\text { Single dose fexofenadine } \\
180 \mathrm{mg} \\
\text { Single dose levocetirizine } \\
5 \mathrm{mg} \\
\text { Placebo }\end{array}$ & $\begin{array}{l}\text { Significant attenuation of } \\
\text { the maximum fall in the } \\
\text { baseline PNIF with all three } \\
\text { active treatments compared } \\
\text { to placebo. } \\
\text { Significant attenuation of } \\
\text { the area under the curve for } \\
60 \text { minutes time-response } \\
\text { measures with all active } \\
\text { treatments compared to } \\
\text { placebo. } \\
\text { Equal efficiency of all three } \\
\text { treatments in attenuating the } \\
\text { allergic reaction to nasal } \\
\text { AMP. }\end{array}$ \\
\hline $\begin{array}{l}\text { Ciprandi } \\
\text { et al./ } \\
2004\end{array}$ & $\begin{array}{l}\text { Randomized } \\
\text { double-blind, } \\
\text { parallel- } \\
\text { group, } \\
\text { placebo- } \\
\text { controlled }\end{array}$ & $\begin{array}{l}>18 \text { years old, } \\
\text { history of PAR for } \\
\text { the last } 2 \text { years, } \\
\text { rhinitis symptoms in } \\
\text { the last } 2 \text { weeks, } \\
\text { baseline TSS } \geq 6, \\
\text { moderate/severe } \\
\text { nasal obstruction }\end{array}$ & 30 & $\begin{array}{l}\text { Desloratadine } 5 \mathrm{mg} / \text { daily } \\
\text { Levocetirizine } 5 \mathrm{mg} / \text { daily } \\
\text { Placebo }\end{array}$ & $\begin{array}{l}\text { Superior efficacy of both } \\
\text { desloratadine and } \\
\text { levocetirizine to placebo in } \\
\text { decreasing TSS and } \\
\text { individual symptoms. } \\
\text { Significant increase in the } \\
\text { nasal airflow and } \\
\text { significantly lower } \\
\text { reversibility of nasal } \\
\text { airflow, with levocetirizine } \\
\text { compared to baseline but } \\
\text { not with desloratadine. } \\
\text { Both treatments superior to } \\
\text { placebo in increasing the } \\
\text { nasal airflow and lowering } \\
\text { the reversibility of nasal } \\
\text { airflow. } \\
\text { Significant reduction in the } \\
\text { number of eosinophils } \\
\text { compared to pre-treatment } \\
\text { baseline with levocetirizine. } \\
\text { Both medications superior } \\
\text { to placebo in reducing } \\
\text { eosinophils. }\end{array}$ \\
\hline
\end{tabular}




\begin{tabular}{|c|c|c|c|c|c|}
\hline Authors & methodology & Inclusion criteria & $\begin{array}{l}\text { No. of } \\
\text { patient } \\
\text { s } \\
\end{array}$ & Comparator regimens & Outcomes and results \\
\hline $\begin{array}{l}\text { Bocşan et } \\
\text { al./ } 2015\end{array}$ & $\begin{array}{l}\text { Randomized } \\
\text { clinical trial }\end{array}$ & $\begin{array}{l}\text { Inclusion: Patients } \\
\text { with ARIA-defined } \\
\text { PAR, no history of } \\
\text { atopy }\end{array}$ & 85 & $\begin{array}{l}\text { Desloratadine } 5 \mathrm{mg} / \text { daily } \\
\text { Levocetirizine } 5 \mathrm{mg} / \text { daily } \\
\text { (For four weeks) }\end{array}$ & $\begin{array}{l}\text { Significant but comparable } \\
\text { reduction in the TSS by } \\
\text { both medications. } \\
\text { Significant alleviation of the } \\
\text { individual symptoms but } \\
\text { levocetirizine superior to } \\
\text { desloratadine in alleviating } \\
\text { nasal congestion. } \\
\text { Significant reduction in } \\
\text { inflammatory cytokines } \\
\text { including IL-1 } \beta \text {, IL- } 6 \text {, IL-8, } \\
\text { and TNF- } \alpha \text { with both active } \\
\text { treatments but more } \\
\text { pronounced effect with } \\
\text { levocetirizine than } \\
\text { desloratadine. }\end{array}$ \\
\hline $\begin{array}{l}\text { Ciebiada } \\
\text { et al./ } \\
2006\end{array}$ & $\begin{array}{l}\text { Randomized, } \\
\text { double-blind, } \\
\text { placebo- } \\
\text { controlled } \\
\text { crossover } \\
\text { trial using } 2 \\
\text { arms }\end{array}$ & $\begin{array}{l}18 \text { to } 65 \text { years old; } \\
\text { ARIA-defined PAR } \\
\text { for } \geq 2 \text { years, nasal } \\
\text { congestion score } \geq 2 \text {, } \\
\text { sensitization to } \\
\text { perennial allergens } \\
\text { relevant to Central } \\
\text { Europe, positive skin } \\
\text { prick test }\end{array}$ & 40 & $\begin{array}{l}\text { First arm: } \\
\text { Desloratadine } 5 \mathrm{mg} / \text { day } \\
\text { Montelukast } 10 \mathrm{mg} / \text { day } \\
\text { Combination of both } \\
\text { Placebo } \\
\text { Second arm: } \\
\text { Levocetirizine } 5 \mathrm{mg} / \text { day } \\
\text { Montelukast } 10 \mathrm{mg} / \text { day } \\
\text { Combination of both } \\
\text { Placebo }\end{array}$ & $\begin{array}{l}\text { Significant attenuation of } \\
\text { the TSS, daytime nasal } \\
\text { scores, and daytime ocular } \\
\text { scores with the combination } \\
\text { therapy. } \\
\text { Significant improvement in } \\
\text { the individual nasal } \\
\text { symptoms such as } \\
\text { congestion and ocular } \\
\text { symptoms with } \\
\text { desloratadine + montelukast } \\
\text { combination than } \\
\text { desloratadine or } \\
\text { montelukast alone. } \\
\text { Significantly better outcome } \\
\text { in reduction of eosinophil } \\
\text { cationic protein with } \\
\text { montelukast + desloratadine } \\
\text { combination but not with } \\
\text { levocetirizine combination } \\
\text { Significant increase in the } \\
\text { minimal cross-sectional area } \\
\text { of the nasal cavity than the } \\
\text { baseline and the placebo, } \\
\text { but not compared with } \\
\text { monotherapy. }\end{array}$ \\
\hline
\end{tabular}

\section{Desloratadine vs. Other Treatment Agents}

The efficacy of desloratadine $5 \mathrm{mg}$, fexofenadine $180 \mathrm{mg}$, and levocetirizine $5 \mathrm{mg}$, three of the recent second-generation antihistamines was comparatively assessed in a randomized double-blind cross-over trial in patients with $\mathrm{PAR}^{38}$. Overall, the three agents demonstrated equal efficiency in attenuating the allergic reaction to nasal adenosine 5monophosphate (AMP). Administering all three treatments resulted in significant attenuation of the maximum drop in the baseline PNIF and the area under the curve for 60 minutes time-response measures compared to placebo $^{38}$.

Both desloratadine and levocetirizine 5 $\mathrm{mg}$ /daily demonstrated superior effectiveness than the placebo in decreasing TSS, individual symptoms, and levels of inflammatory cytokines such as IL-1 $\beta$, IL-4, IL-6, IL-8, and 
TNF- $\alpha^{39 \& 40}$. This effect was more pronounced with levocetirizine than desloratadine ${ }^{39}$. Also, levocetirizine had significant superiority to desloratadine in improving nasal airflow, achieving lower reversibility in nasal airflow after induced vasoconstriction, caused a significant increase in total nasal airflow, and reduction in the number of eosinophils ${ }^{39 \& 40}$.

The combination therapy of montelukast with desloratadine or levocetirizine offered a number of advantages over monotherapy such as significant attenuation of the TSS, daytime nasal scores, and daytime ocular scores. Specifically, in the montelukast-desloratadine combination, there was a significant improvement in the individual nasal and ocular symptoms compared to desloratadine or montelukast alone. Moreover, montelukastdesloratadine combination resulted in a significantly better outcome than montelukastlevocetirizine in reduction of eosinophil cationic protein as an inflammatory mediator ${ }^{41}$.

The efficacy of desloratadine in combination with prednisolone was compared with dexchlorpheniramine/betamethasone combination among children 2-12 years old presenting with moderate to severe $\mathrm{PAR}^{42}$. Significant reduction in nasal and extra-nasal symptoms was achieved by both compounds separately and this reduction was comparable between treatments. In the subjective evaluation more than $90 \%$ of the subjects in both treatment groups indicated feeling better/much better after the treatment.

\section{Chronic Idiopathic Urticaria Desloratadine vs. Placebo}

Desloratadine has a potential role of oxidative stress in the pathogenesis of chronic idiopathic urticaria (CIU). Desloratadine treatment was also associated with a significant decrease in the levels of alph-1, alpha-2, beta-1 globulins, c-reactive protein, and albumin as inflammation indicators. In patients with chronic spontaneous urticaria (CSU), desloratadine resulted in a significant decrease in leucocytes and basophils compared to before treatment with no significant effect on other hematologic parameters such as neutrophils, lymphocytes, and monocytes ${ }^{43}$. The positive impact of desloratadine on QoL was demonstrated by some studies ${ }^{44-46}$.

Response to desloratadine treatment in one study was rated as either a complete relief or a marked relief equally by one-thirds of the patients ${ }^{46}$. Desloratadine group also achieved a significantly better CIU improvement with nearly $70 \%$ of the subjects reporting complete relief ${ }^{47}$. Moreover, desloratadine has resulted in significant improvement in interference with sleep and improved sleep as well as interference/disruption in daily activities scores ${ }^{12 \& 44 \& 45 \& 48-50}$. Physician-rated evaluations also show that general state of urticaria also experienced a significant improvement with desloratadine therapy where, according to physician reports more than $88 \%$ of the patients achieved wither complete or significant symptom relief ${ }^{48}$.

In a number of studies of varying methodologies such as RCT and postmarketing surveillances involving patients with CIU, desloratadine has been shown to be significantly effective in improving the total CIU symptom scores, attenuating the CIU related pruritus and itching severity, and improving mean morning/evening reflective pruritus scores ${ }^{12 \& 43 \& 45 \& 47-50}$. Similarly, desloratadine treatment has shown to significantly reduce the number and size of the wheals, and the size of the largest whealscores ${ }^{12 \& 43 \& 45 \& 47-50}$.

\section{Desloratadine vs. Other Treatment Agents}

A comparative study of efficacy and safety of rupatadine versus desloratadine therapy in patients with CIU showed the superior safety and efficacy of rupatadine in reducing the eosinophil count, serum IgE levels, and the number of wheals, as well as significantly greater improvement in the AEQLQ ${ }^{51 \& 52}$. In another RCT, the efficacy of rupatadine was compared to desloratadine in pediatric patients aged between 2 to 11 years old with $\mathrm{CSU}^{52}$. All active agents showed significant efficacy in improving the urticaria activity scores, but no differences were present between treatments. Both agents were significantly more effective 
than placebo in improving mean pruritus scores but superiority of rupatadine to desloratadine was observed. In this study, both treatments resulted in a significant improvement in children's QoL ${ }^{52}$.

Desloratadine did not show superiority to levocetirizine in managing $\mathrm{CIU}^{53}$. A significantly greater decrease was achieved with levocetirizine in pruritus symptom severity scores as well as the sum of the pruritus severity score and the score for the numbers of wheals throughout the 4-week treatment period $^{53}$. Moreover, relative to desloratadine, levocetirizine was significantly more effective in reducing the duration of pruritus symptoms ${ }^{53}$. Levocetirizine showed superiority to desloratadine in the overall success rate. In non-responders to the maximum dose of one medication, switching desloratadine to levocetirizine resulted in $30 \%$ improvement, while no benefit was obtained with switching to desloratadine ${ }^{54}$. Moreover, the results of the improvement level of urticaria-associated discomfort significantly favored levocetirizine over desloratadine. Assessment of the QoL components showed an increasing trend of QoL with increasing the dose of both medications with levocetirizine demonstrating superiority to desloratadine ${ }^{54}$.

Another study took a different approach by seeking to understand the effect of adding dipyridamole to desloratadine therapy in managing the patients with chronic urticaria ${ }^{55}$. This study was based on the notion that platelets are involved in the inflammatory reactions through their proinflammatory properties leading to the release of inflammatory mediators when activated. Desloratadine and dipyridamole combination had a significantly greater clinical effectiveness compared to desloratadine alone as $85 \%$ percent versus $70 \%$ attained complete cure or obvious improvement of their CIU based on Symptom Score Reduce Index, respectively ${ }^{55}$. Both treatments significantly reduced the wheals and pruritus scores, though such decrease in symptoms was greater with the combination therapy. Moreover, the recurrence rate of symptoms after the treatment withdrawal was considerably lower in the combination therapy group compared to desloratadine monotherapy ( $24 \%$ vs. $53 \%)^{55}$.

Desloratadine and montelukast combination did not provide a marked advantage in reliving CIU symptoms as the effectiveness of desloratadine alone versus desloratadine and montelukast combination were similar in all these efficacy parameters ${ }^{56}$. Superior efficacy of desloratadine and desloratadine/montelukast was observed compared to montelukast alone in alleviating pruritus. Desloratadine monotherapy and desloratadine/montelukast combination were also significantly more effective than montelukast monotherapy in reducing the TSS, pruritus, number, and size of hives, although all treatments improved these measures. In terms of the improving the CIU interference with sleep, both desloratadine mono- and combination therapy showed significant efficacy than placebo and montelukast monotherapy ${ }^{56}$.

Higher efficacy of desloratadine was observed compared with previous antihistamine monotherapy including cetirizine, loratadine, and fexofenadine, desloratadine in a postmarketing surveillance study ${ }^{48}$. Also, more than half of the previous antihistamine users reported receiving a faster alleviation with desloratadine than the previous medication ${ }^{48}$. 
Table 3: An overview of the research studies on clinical efficacy of desloratadine compared to placebo, baseline measures, or other treatment agents in treatment of chronic idiopathic urticaria

\begin{tabular}{|c|c|c|c|c|c|}
\hline Authors & Methodology & Inclusion criteria & $\begin{array}{l}\text { No. of } \\
\text { patients }\end{array}$ & $\begin{array}{l}\text { Comparator } \\
\text { regimens }\end{array}$ & Outcomes and results \\
\hline $\begin{array}{l}\text { Maaouia } \\
\text { et al./ } \\
2016\end{array}$ & $\begin{array}{l}\text { Prospective } \\
\text { case-control } \\
\text { design }\end{array}$ & $\begin{array}{l}\text { CSU confirmed by } \\
\text { urticarial skin } \\
\text { lesions, intermittent } \\
\text { or continuous for }>6 \\
\text { weeks }\end{array}$ & $\begin{array}{l}30 \mathrm{CSU} \\
\text { patients } \\
\text { and } 30 \\
\text { controls }\end{array}$ & $\begin{array}{l}\text { Desloratadine } \\
5 \mathrm{mg} / \text { day } \\
\text { (For } 30 \text { days) }\end{array}$ & $\begin{array}{l}\text { Marked reduction in the } \\
\text { wheal size and itching } \\
\text { severity with } \\
\text { desloratadine } \\
\text { Significant decrease in } \\
\text { the levels of alpha-1, } \\
\text { alpha-2, beta-1 globulins, } \\
\text { CRP and albumin as } \\
\text { inflammation indicators } \\
\text { Significant decrease in } \\
\text { leucocytes and basophils } \\
\text { compared to before } \\
\text { treatment but no } \\
\text { significant effect on other } \\
\text { hematologic parameters. }\end{array}$ \\
\hline $\begin{array}{l}\text { Lachapelle } \\
\text { et al./ } \\
2005\end{array}$ & $\begin{array}{l}\text { Prospective } \\
\text { before and } \\
\text { after study }\end{array}$ & $\begin{array}{l}\text { CIU } \geq 6 \text { weeks, } \\
\text { current flare of } \geq 3 \\
\text { weeks, } \geq 18 \text { years } \\
\text { old, no child-bearing } \\
\text { potential, using an } \\
\text { acceptable method of } \\
\text { birth control, free of } \\
\text { any diseases or } \\
\text { medication that may } \\
\text { interfere with the } \\
\text { study }\end{array}$ & $\begin{array}{l}121 \\
\text { consecutive } \\
\text { patients }\end{array}$ & $\begin{array}{l}\text { Desloratadine } \\
5 \text { mg daily } \\
\text { (For } 42 \text { days) }\end{array}$ & $\begin{array}{l}\text { Significant improvement } \\
\text { in the total and sub-total } \\
\text { QoL scores (except work } \\
\text { and school component) } \\
\text { evident at day } 7 \text { and day } \\
42 . \\
\text { Complete relief of the } \\
\text { symptoms or marked } \\
\text { relief equally by one-third } \\
\text { of the patients. }\end{array}$ \\
\hline $\begin{array}{l}\text { Monroe et } \\
\text { al./ } 2003\end{array}$ & $\begin{array}{l}\text { Double-blind, } \\
\text { randomized, } \\
\text { placebo- } \\
\text { controlled } \\
\text { trial }\end{array}$ & $\begin{array}{l}\geq 12 \text { years old; } \\
\text { documented CIU } \geq 6 \\
\text { weeks; CIU flare } \geq 3 \\
\text { weeks; urticarial } \\
\text { lesions } \geq 3 \\
\text { days/week; at least } \\
\text { moderate severity } \\
\text { CIU at screening and } \\
\text { baseline; at least } \\
\text { moderate pruritus, } \\
\text { and visible hives, } \\
\text { total reflective } \\
\text { pruritus score } \geq 14 \text { in } \\
\text { last } 3 \text { days of } \\
\text { screening, normal } \\
\text { lab/ECG values, } \\
\text { negative serum } \\
\text { pregnancy test and } \\
\text { acceptable } \\
\text { contraception } \\
\text { method }\end{array}$ & 226 & $\begin{array}{l}\text { Desloratadine } \\
5 \mathrm{mg} / \text { daily } \\
\text { Placebo } \\
\text { (For } 6 \text { weeks) }\end{array}$ & $\begin{array}{l}\text { Significantly superior } \\
\text { efficacy of desloratadine } \\
\text { in improving the total } \\
\text { CIU symptom scores. } \\
\text { Significant attenuation of } \\
\text { symptoms including } \\
\text { pruritus, the number of } \\
\text { hives, and the size of the } \\
\text { largest hive. } \\
\text { Significant reduction in } \\
\text { sleep disturbance and } \\
\text { improvement of the } \\
\text { performance of daily } \\
\text { activities. } \\
\text { Sustained efficacy from } \\
\text { the first } 24 \text { hours } \\
\text { throughout the entire } \\
\text { duration of the study. } \\
\text { Similar incidence of AEs } \\
\text { between desloratadine } \\
\text { and placebo. }\end{array}$ \\
\hline
\end{tabular}




\begin{tabular}{|c|c|c|c|c|c|}
\hline Authors & Methodology & Inclusion criteria & $\begin{array}{l}\text { No. of } \\
\text { patients }\end{array}$ & $\begin{array}{l}\text { Comparator } \\
\text { regimens }\end{array}$ & Outcomes and results \\
\hline $\begin{array}{l}\text { Ortonne et } \\
\text { al./ } 2007\end{array}$ & $\begin{array}{l}\text { Randomized } \\
\text { double-blind } \\
\text { placebo- } \\
\text { controlled } \\
\text { trial }\end{array}$ & $\begin{array}{l}\geq 18 \text { years old, } \\
\text { previous diagnosis of } \\
\text { CIU, having active } \\
\text { moderate-to-severe } \\
\text { CIU, an active CIU } \\
\text { flare of } \geq 3 \text { weeks, } \\
\text { wheals present } \geq 3 \\
\text { days/week, global } \\
\text { CIU severity score } \geq \\
2 \text {, required washout } \\
\text { period for a specified } \\
\text { list of medications } \\
\text { such as } \\
\text { corticosteroids, } \\
\text { antihistamines, } \\
\text { NSAIDs, etc. }\end{array}$ & 137 & $\begin{array}{l}\text { Desloratadine } \\
5 \mathrm{mg} \text { once } \\
\text { daily } \\
\text { Placebo } \\
\text { (For } 6 \text { weeks) }\end{array}$ & $\begin{array}{l}\text { Significantly superior } \\
\text { efficacy of desloratadine } \\
\text { than placebo in improving } \\
\text { the pruritus scores. } \\
\text { Significant reduction in } \\
\text { the sizes of the largest } \\
\text { wheals. } \\
\text { Significant reduction in } \\
\text { the number of wheals } \\
\text { from the week } 2 \text { of the } \\
\text { study onwards. } \\
\text { Significantly better CIU } \\
\text { improvement with nearly } \\
70 \% \text { of the subjects } \\
\text { reporting complete relief } \\
\text { with desloratadine } \\
\text { therapy. } \\
\text { Sustained efficacy } \\
\text { throughout the study } \\
\text { period. }\end{array}$ \\
\hline $\begin{array}{l}\text { Kim and } \\
\text { Lynde/ } \\
2008\end{array}$ & $\begin{array}{l}\text { Open-label, } \\
\text { observational, } \\
\text { multicenter } \\
\text { study }\end{array}$ & $\begin{array}{l}\geq 18 \text { years old; CIU } \\
\text { diagnosis; a hive } \\
\text { score } \geq 1, \text { pruritus } \\
\text { score } \geq 2, \text { overall } \\
\text { condition score } \geq 2, \\
\text { 6-week history of } \\
\text { CIU, a current flare } \\
\text { of } \geq 3 \text {-weeks }\end{array}$ & 348 & $\begin{array}{l}\text { Desloratadine } \\
5 \text { mg daily } \\
\text { compared to } \\
\text { the baseline } \\
\text { (For } 14 \text { days) }\end{array}$ & $\begin{array}{l}\text { Significant reduction in } \\
\text { the overall condition } \\
\text { score. } \\
\text { Significant reduction in } \\
\text { itching scores. } \\
\text { Significant reduction in } \\
\text { hive scores and the size of } \\
\text { the hives. } \\
\text { Significant improvement } \\
\text { in interference with sleep } \\
\text { and interference with } \\
\text { daily outdoor activities. } \\
\text { Significant improvement } \\
\text { in all ten domains of the } \\
\text { AEQLQ QoL tool. }\end{array}$ \\
\hline $\begin{array}{l}\text { Ring et al./ } \\
2001\end{array}$ & $\begin{array}{l}\text { Multicentre, } \\
\text { randomized, } \\
\text { double-blind, } \\
\text { placebo- } \\
\text { controlled } \\
\text { study }\end{array}$ & $\begin{array}{l}\geq 12 \text { years old, } \geq 6 \text { - } \\
\text { week CIU history, } \\
\text { active flare } \geq 3 \\
\text { weeks, wheals } \\
\text { visible for } \geq 3 \\
\text { days/week, at least } \\
\text { moderate disease } \\
\text { severity at screening } \\
\text { and baseline, at least } \\
\text { moderate pruritus } \\
\text { and wheals at } \\
\text { screening, total } \\
\text { reflective pruritus } \\
\text { score } \geq 14 \text { over } \\
\text { previous } 3 \text { days and } \\
\text { the morning of the } \\
\text { baseline visit, } \\
\text { clinical/laboratory } \\
\text { tests within } \\
\text { acceptable range } \\
\end{array}$ & 190 & $\begin{array}{l}\text { Desloratadine } \\
5 \mathrm{mg} \text { once } \\
\text { daily } \\
\text { Placebo } \\
\text { (For } 6 \text { weeks) }\end{array}$ & $\begin{array}{l}\text { Superior efficacy to } \\
\text { placebo in reducing the } \\
\text { average mean } \\
\text { morning/evening } \\
\text { reflective pruritus score. } \\
\text { Significant improvement } \\
\text { in the morning/evening } \\
\text { reflective TSS compared } \\
\text { to placebo. } \\
\text { Significant reduction in } \\
\text { the morning instantaneous } \\
\text { pruritus scores. } \\
\text { Significant improvement } \\
\text { in sleep and daily activity } \\
\text { scores. } \\
\text { Highly significant } \\
\text { reduction in the number } \\
\text { of hives and the size of } \\
\text { the largest hives. }\end{array}$ \\
\hline
\end{tabular}




\begin{tabular}{|c|c|c|c|c|c|}
\hline Authors & Methodology & Inclusion criteria & $\begin{array}{l}\text { No. of } \\
\text { patients }\end{array}$ & $\begin{array}{l}\text { Comparator } \\
\text { regimens }\end{array}$ & Outcomes and results \\
\hline $\begin{array}{l}\text { Grob et } \\
\text { al./ } 2007\end{array}$ & $\begin{array}{l}\text { Multicentre, } \\
\text { randomized, } \\
\text { double-blind } \\
\text { placebo- } \\
\text { controlled } \\
\text { study }\end{array}$ & $\begin{array}{l}\geq 18 \text { years old, } \\
\text { history of CIU with } \\
\text { symptoms present } \\
\text { for } 3 \text { weeks, wheals } \\
\text { present for } 3 \text { days/ } \\
\text { week, flare-up before } \\
\text { first visit, good } \\
\text { general health, using } \\
\text { an effective method } \\
\text { of contraception, } \\
\text { pruritus score of } 2 \text {, } \\
\text { wheal score of } 1 \text {, } \\
\text { global CIU severity } \\
\text { score of } 2 \text { at } \\
\text { screening and } \\
\text { baseline, } \\
\text { morning/evening } \\
\text { reflective pruritus } \\
\text { score of } 14 \text { for three } \\
\text { consecutive days } \\
\text { prior to study }\end{array}$ & 137 & $\begin{array}{l}\text { Desloratadine } \\
5 \text { mg once } \\
\text { daily } \\
\text { Placebo } \\
\text { (For } 42 \text { days) }\end{array}$ & $\begin{array}{l}\text { Significantly greater } \\
\text { overall improvement in } \\
\text { QoL than the baseline } \\
\text { scores compared to the } \\
\text { placebo with both DLQI } \\
\text { and VQ Dermato QoL } \\
\text { assessment tools. } \\
\text { Significant improvement } \\
\text { in sleep disruption } \\
\text { components and } \\
\text { reduction in the } \\
\text { disruption of daily } \\
\text { activities score from the } \\
\text { beginning to the end of } \\
\text { the study period. }\end{array}$ \\
\hline $\begin{array}{l}\text { Augusting } \\
\text { and Ehrle/ } \\
2009\end{array}$ & $\begin{array}{l}\text { Observational } \\
\text { post- } \\
\text { marketing } \\
\text { surveillance } \\
\text { study }\end{array}$ & $\begin{array}{l}\text { Patients with CIU } \\
\text { aged } \geq 12 \text { years old, } \\
\text { meeting the } \\
\text { desloratadine } \\
\text { treatment criteria as } \\
\text { outlined in the } \\
\text { package insert }\end{array}$ & 9,246 & $\begin{array}{l}\text { Desloratadine } \\
\text { Baseline } \\
\text { Any previous } \\
\text { antihistamine } \\
\text { therapy }\end{array}$ & $\begin{array}{l}\text { Significant decrease in } \\
\text { the symptoms of } \\
\text { itching/pruritus, number } \\
\text { of wheals, and the size of } \\
\text { the largest wheal. } \\
\text { Significant patient- } \\
\text { reported improvement in } \\
\text { CIU-impaired sleep and } \\
\text { daily activities. } \\
\text { More than } 88 \% \text { complete } \\
\text { or significant symptom } \\
\text { relief with desloratadine } \\
\text { treatment. } \\
\text { Superior efficacy and } \\
\text { earlier onset of action } \\
\text { compared with previous } \\
\text { antihistamine treatments } \\
\text { with cetirizine, loratadine, } \\
\text { and fexofenadine. }\end{array}$ \\
\hline $\begin{array}{l}\text { Bachert } \\
\text { and } \\
\text { Maurer/ } \\
2010\end{array}$ & $\begin{array}{l}\text { Four } \\
\text { prospective } \\
\text { post- } \\
\text { marketing } \\
\text { surveillance } \\
\text { studies }\end{array}$ & $\begin{array}{l}\geq 12 \text { years old with } \\
\text { SAR or CIU treated } \\
\text { with desloratadine }\end{array}$ & $\begin{array}{l}\text { Overall, } \\
77,880 \\
\text { subjects } \\
\text { with } \\
9,246+ \\
13,183 \\
\text { having CIU }\end{array}$ & \begin{tabular}{|l} 
Desloratadine \\
5 mg once \\
daily \\
compared to \\
baseline \\
(Mean \\
duration of \\
40.4 days)
\end{tabular} & $\begin{array}{l}\text { Significant improvement } \\
\text { in total urticaria } \\
\text { symptoms. } \\
\text { Significant reduction in } \\
\text { the severity of itching, } \\
\text { number of wheals and } \\
\text { diameter of the largest } \\
\text { wheal. } \\
\text { Significant effect on sleep } \\
\text { and daily activity } \\
\text { improvement with } \\
\text { desloratadine. }\end{array}$ \\
\hline
\end{tabular}




\begin{tabular}{|c|c|c|c|c|c|}
\hline Authors & Methodology & Inclusion criteria & $\begin{array}{l}\text { No. of } \\
\text { patients }\end{array}$ & $\begin{array}{l}\text { Comparator } \\
\text { regimens }\end{array}$ & Outcomes and results \\
\hline $\begin{array}{l}\text { Kolasani } \\
\text { et al./ } \\
2013\end{array}$ & $\begin{array}{l}\text { Prospective, } \\
\text { randomized, } \\
\text { open, } \\
\text { outdoor- } \\
\text { based clinical } \\
\text { study }\end{array}$ & $\begin{array}{l}12 \text { - } 60 \text { years old; } \\
\text { CIU diagnosis }\end{array}$ & 56 & $\begin{array}{l}\text { Desloratadine } \\
5 \text { mg daily } \\
\text { Rupatadine } \\
10 \mathrm{mg} \text { daily } \\
\text { Placebo } \\
\text { (For } 4 \text { weeks) }\end{array}$ & $\begin{array}{l}\text { Superior efficacy of } \\
\text { rupatadine over } \\
\text { desloratadine in } \\
\text { improving the TSS and } \\
\text { the AEQLQ, though both } \\
\text { medications significantly } \\
\text { superior to placebo. } \\
\text { Rupatadine superior over } \\
\text { desloratadine in reducing } \\
\text { the eosinophil count and } \\
\text { serum IgE levels. } \\
\text { Lower (but non- } \\
\text { significant) incidence of } \\
\text { AEs with rupatadine. }\end{array}$ \\
\hline $\begin{array}{l}\text { Potter et } \\
\text { al./ } 2009\end{array}$ & $\begin{array}{l}\text { Multi-center, } \\
\text { randomized, } \\
\text { double-blind } \\
\text { study }\end{array}$ & $\begin{array}{l}\geq 18 \text { years old; } \\
\text { history of CIU } \geq 6 \\
\text { weeks in the last } 3 \\
\text { months; pruritus } \\
\text { severity score } \geq 2 ; \\
\text { wheal score } \geq 1 \text { for } \geq \\
3 \text { days/week prior to } \\
\text { study }\end{array}$ & 886 & \begin{tabular}{|l} 
Desloratadine \\
$5 \mathrm{mg}$ once \\
daily \\
\\
Levocetirizine \\
$5 \mathrm{mg}$ once \\
daily \\
(For 4 weeks)
\end{tabular} & $\begin{array}{l}\text { Significantly greater } \\
\text { decrease with } \\
\text { levocetirizine in pruritus } \\
\text { severity scores and the } \\
\text { sum of the pruritus } \\
\text { severity score + the } \\
\text { numbers of wheals } \\
\text { compared to } \\
\text { desloratadine. } \\
\text { Significantly more } \\
\text { efficacy with } \\
\text { levocetirizine than } \\
\text { desloratadine in reducing } \\
\text { the duration of pruritus } \\
\text { symptoms. } \\
\text { Improved DLQI QoL } \\
\text { measures with both } \\
\text { treatments. } \\
\text { Reduced CIU impact on } \\
\text { sleep with both } \\
\text { treatments. }\end{array}$ \\
\hline
\end{tabular}




\begin{tabular}{|c|c|c|c|c|c|}
\hline Authors & Methodology & Inclusion criteria & $\begin{array}{l}\text { No. of } \\
\text { patients }\end{array}$ & $\begin{array}{l}\text { Comparator } \\
\text { regimens }\end{array}$ & Outcomes and results \\
\hline $\begin{array}{l}\text { Khalaf et } \\
\text { al./ } 2007\end{array}$ & $\begin{array}{l}\text { Randomized, } \\
\text { double-blind; } \\
\text { parallel group } \\
\text { study }\end{array}$ & $\begin{array}{l}\geq 16 \text { years old, } \\
\text { documented history } \\
\text { of } C U \geq 6 \text { weeks } \\
\text { with a frequency of } \geq \\
3 \text { episodes/week, } \\
\text { stopping } \\
\text { corticosteroids } 1 \\
\text { month before the } \\
\text { study and other } \\
\text { preventive or } \\
\text { treatment agents one } \\
\text { week prior }\end{array}$ & 64 & $\begin{array}{l}\text { Desloratadine } \\
5 \mathrm{mg} / \text { day }+ \\
\text { dipyridamole } \\
25 \mathrm{mg} \text { TDS } \\
\\
\text { Desloratadine } \\
5 \mathrm{mg} / \text { day }+ \\
\text { placebo }\end{array}$ & $\begin{array}{l}\text { Significantly greater } \\
\text { clinical effectiveness with } \\
\text { desloratadine and } \\
\text { dipyridamole } \\
\text { combination compared to } \\
\text { desloratadine alone ( } 85 \% \\
\text { percent versus } 70 \% \\
\text { complete cure or obvious } \\
\text { improvement of CIU, } \\
\text { respectively). } \\
\text { Significant reduction in } \\
\text { the wheals and pruritus } \\
\text { scores with both } \\
\text { treatments, but a greater } \\
\text { decrease in symptoms } \\
\text { with the combination } \\
\text { therapy. } \\
\text { Lower recurrence rate of } \\
\text { symptoms after the } \\
\text { treatment withdrawal in } \\
\text { the combination therapy } \\
\text { group compared to } \\
\text { desloratadine } \\
\text { monotherapy (24\% vs. } \\
\text { 53\%). }\end{array}$ \\
\hline $\begin{array}{l}\text { Lorenzo et } \\
\text { al./ } 2004\end{array}$ & $\begin{array}{l}\text { Randomized, } \\
\text { double-blind, } \\
\text { double- } \\
\text { dummy, } \\
\text { placebo- } \\
\text { controlled, } \\
\text { parallel-group } \\
\text { study }\end{array}$ & $\begin{array}{l}\text { 18-69 years old, CIU } \\
\text { diagnosis (presence } \\
\text { of urticarial lesions } \\
\text { for }>6 \text { weeks with > } \\
3 \text { episodes per } \\
\text { week), no secondary } \\
\text { known causes }\end{array}$ & 160 & $\begin{array}{l}\text { Desloratadine } \\
5 \mathrm{mg} \text { daily + } \\
\text { Placebo } \\
\\
\text { Montelukast } \\
10 \mathrm{mg}+ \\
\text { Placebo } \\
\\
\text { Desloratadine } \\
5 \mathrm{mg}+ \\
\text { Montelukast } \\
10 \mathrm{mg}\end{array}$ & $\begin{array}{l}\text { Significant improvement } \\
\text { in the TSS, number of } \\
\text { hives, and the size of the } \\
\text { largest hive with all } \\
\text { treatments. } \\
\text { No marked advantage } \\
\text { with desloratadine and } \\
\text { montelukast combination } \\
\text { than desloratadine alone. } \\
\text { Similar efficacy of } \\
\text { desloratadine alone } \\
\text { versus } \\
\text { desloratadine/montelukast } \\
\text { combination in all the } \\
\text { efficacy parameters. } \\
\text { Superior efficacy of } \\
\text { desloratadine and } \\
\text { desloratadine/montelukast } \\
\text { compared to montelukast } \\
\text { alone in alleviating } \\
\text { pruritus. } \\
\text { Significant efficacy of } \\
\text { desloratadine mono- and } \\
\text { combination therapy than } \\
\text { montelukast monotherapy } \\
\text { in improving sleep } \\
\text { interference. }\end{array}$ \\
\hline
\end{tabular}




\begin{tabular}{|c|c|c|c|c|c|}
\hline Authors & Methodology & Inclusion criteria & $\begin{array}{l}\text { No. of } \\
\text { patients }\end{array}$ & $\begin{array}{l}\text { Comparator } \\
\text { regimens }\end{array}$ & Outcomes and results \\
\hline $\begin{array}{l}\text { Potter et } \\
\text { al./ } 2015\end{array}$ & $\begin{array}{l}\text { Randomized, } \\
\text { double blind, } \\
\text { placebo- and } \\
\text { desloratadine- } \\
\text { controlled } \\
\text { study }\end{array}$ & $\begin{array}{l}\text { Children aged } 2-11 \\
\text { years old with CSU, } \\
\text { weighing } \geq 10 \mathrm{~kg} \text {, } \\
\text { documented history } \\
\text { of CSU with or } \\
\text { without angioedema } \\
\geq 6, \text { Urticaria } \\
\text { Activity Score } 7 \text { days } \\
\text { cumulative score } \geq \\
12 \text { points; normal } \\
\text { ECG values }\end{array}$ & 206 & \begin{tabular}{|l}
$\begin{array}{l}\text { Rupatadine } \\
\text { oral solution } 1 \\
\mathrm{mg} / \mathrm{ml} \text { once } \\
\text { daily }\end{array}$ \\
Desloratadine \\
$0.5 \mathrm{mg} / \mathrm{ml}$ \\
once daily \\
Placebo \\
(For 6 weeks)
\end{tabular} & $\begin{array}{l}\text { Significant improvement } \\
\text { by all active agents in } \\
\text { improving the Urticaria } \\
\text { Activity Scores but no } \\
\text { between-treatment } \\
\text { differences. } \\
\text { Rupatadine more } \\
\text { effective than } \\
\text { desloratadine in reducing } \\
\text { the mean number of } \\
\text { wheals. } \\
\text { Both agents significantly } \\
\text { effective than placebo in } \\
\text { improving absolute } \\
\text { change mean pruritus } \\
\text { scores but superiority of } \\
\text { rupatadine in improving } \\
\text { mean pruritus score to } \\
\text { desloratadine. } \\
\text { Significant improvement } \\
\text { in children's QoL with } \\
\text { both treatments. }\end{array}$ \\
\hline $\begin{array}{l}\text { Staevska } \\
\text { ey al./ } \\
2010\end{array}$ & $\begin{array}{l}\text { Double-blind, } \\
\text { randomized, } \\
2 \text { parallel- } \\
\text { armed trial }\end{array}$ & $\begin{array}{l}\text { 19-67 years old; } \\
\text { difficult-to-treat } \\
\text { chronic urticaria with } \\
\text { failure to previous } \\
\text { treatment, receiving } \\
\text { intermittent systemic } \\
\text { corticosteroids up to } \\
3 \text { weeks before } \\
\text { inclusion in the } \\
\text { study; } \geq 6 \text {-week } \\
\text { history of moderate/ } \\
\text { severe urticaria }\end{array}$ & 80 & \begin{tabular}{|l} 
Desloratadine \\
$5,10,20 \mathrm{mg}$ \\
once daily \\
Levocetirizine \\
$5,10,20 \mathrm{mg}$ \\
once daily
\end{tabular} & $\begin{array}{l}\text { Significantly more } \\
\text { success rate in achieving } \\
\text { symptom-free state with } \\
\text { increasing the dose of } \\
\text { both medications to more } \\
\text { than } 5 \mathrm{mg} \text { conventional } \\
\text { dose. } \\
\text { Superiority of } \\
\text { levocetirizine to } \\
\text { desloratadine in the } \\
\text { overall success rate. } \\
\text { 30\% improvement after } \\
\text { switching maximum dose } \\
\text { desloratadine to } \\
\text { levocetirizine (bot no } \\
\text { effect with switching } \\
\text { levocetirizine to } \\
\text { desloratadine). } \\
\text { Significant improvement } \\
\text { in urticaria-associated } \\
\text { discomfort in favor of } \\
\text { levocetirizine than } \\
\text { desloratadine. } \\
\text { Increasing trend of QoL } \\
\text { with increasing the dose } \\
\text { of both medications but } \\
\text { superior efficacy with } \\
\text { levocetirizine. }\end{array}$ \\
\hline
\end{tabular}




\section{Other potential indications \\ Uremic Pruritus}

Uremic pruritus is a common complication in dialysis patients. Only one study was found evaluating the efficacy of desloratadine compared with gabapentin in alleviating chronic haemodialysis with sustained pruritus for more than 2 months ${ }^{57}$. Both treatments resulted in an improvement in the severity of pruritus using a visual analogue scale for pruritus scores, of which only desloratadine's effect was statistically significant compared to the baseline. However, none of the agents were superior to the other. The percentage of patients experiencing at least $50 \%$ improvement in their symptoms was significantly higher with desloratadine than gabapentin (58\% vs $16 \%)$.

\section{Cold Urticaria}

Desloratadine has also been proposed to be effective in the treatment of acquired cold urticaria, a condition in which a cold stimulus

provokes the formation of wheals and itching on the skin. Two studies were found investigating the efficacy of desloratadine on treating cold urticaria ${ }^{58 \& 59}$. Desloratadine demonstrated efficacy in reducing the volume of wheals provoked by cold where higher doses of desloratadine was more effective. Thermographic analysis also showed significantly smaller areas of hyperthermic skin lesions with no statistical differences between the doses. Furthermore, the critical temperature threshold (i.e. the maximum temperature causing wheal induction) and the critical stimulation time threshold (i.e. the shortest time required to induce a wheal) were significantly improved with desloratadine administration in both conventional and high $\operatorname{dose}^{59}$.

The second study evaluated the effect of desloratadine $5 \mathrm{mg}$ daily for 4 days in inhibition of cold urticaria among 12 patients by provoking cold with an ice-cube being in contact with the forearm skin ${ }^{58}$. Desloratadine treatment caused a considerable improvement in the symptoms of cold urticaria, reflected as no confluent wheals or itching after the treatment period. Moreover, desloratadine treatment was associated with significantly lower likelihood of producing $\geq 4$ wheals after the cold contact than before treatment ${ }^{58}$. Moreover, it took longer time after desloratadine treatment to generate a weak response ( 7.0 vs $1.2 \mathrm{~min}$ ). Analysis of patient opinions indicated a general satisfaction with desloratadine over previous antihistamine treatments such as cetirizine, loratadine, and cyproheptadine for a number of reasons including less itching, less side effects, and better effectiveness ${ }^{58}$.

\section{Chronic Rhinosinusitis}

One study was found investigating the potential clinical application and efficacy of desloratadine therapy in chronic rhinosinusitis ${ }^{60}$. This study involved 90 patients with chronic sinusitis who had underwent endoscopic sinus surgery and compared the clinical efficacy of the combination of desloratadine citrate disodium with budesonide suspension against budesonide nebulizing suspension ${ }^{60}$. While both treatments resulted in a significant decrease in serum IgE, eosinophils and inflammatory cytokines including IL-6, IL8, TNF- $\alpha$, and hs-CRP. Desloratadine and budesonide combination had a significantly higher efficacy for chronic sinusitis and decreasing inflammatory cytokines ${ }^{60}$.

\section{Chronic Otitis Media}

A retrospective review of case series related to 138 children with chronic otitis media with effusion studied the potential role of desloratadine based on the assumption of the involvement of histamine in the middle ear effusion $^{61}$. Desloratadine was found to be effective in accelerating the alleviation of effusion in the middle ear as demonstrated

\section{REFERENCES}

1. M. S. Dykewicz, D. V. Wallace, F. Baroody, J. Bernstein, T. Craig, I. Finegold, F. Huang, D. LarenasLinnemann, E. Meltzer, G. Steven, "Treatment of seasonal allergic rhinitis: an evidence-based focused 2017 guideline update", Ann Allergy Asthma Immunol, 119, 489-511. e41 (2017).

2. F. Horak, P. Stübner, R. Zieglmeyer, A. Harris, "Comparison of the effects of desloratadine 5-mg daily and placebo on 
nasal airflow and seasonal allergic rhinitis symptoms induced by grass pollen exposure", Allergy, 58, 481-485 (2003).

3. L. M. Salmun, R. Lorber, "24-hour efficacy of once-daily desloratadine therapy in patients with seasonal allergic rhinitis [ISRCTN32042139]." BMC Fam. Pract., 3, 14 (2002).

4. A. Pradalier, C. Neukirch, I. Dreyfus, P. Devillier, "Desloratadine improves quality of life and symptom severity in patients with allergic rhinitis", Allergy, 62, 13311334 (2007).

5. E. O. Meltzer, A. A. Jalowayski, K. Vogt, D. Iezzoni, A. G. Harris, "Effect of desloratadine therapy on symptom scores and measures of nasal patency in seasonal allergic rhinitis: results of a single-center, placebo-controlled trial", Ann. Allergy. Asthma Immunol, 96, 363-368 (2006).

6. E. O. Meltzer, B. M. Prenner, A. Nayak, "Efficacy and Tolerability of Once-Daily 5mg Desloratadine, an $\mathrm{H}$ 1-Receptor Antagonist, in Patients with Seasonal Allergic Rhinitis", Clin Drug Investig, 21, 25-32 (2001).

7. T. M. Adham, "Treatment of allergic rhinitis with desloratadine: results of a multinational observational study in the middle East gulf region", World Allergy Organ J, 4, 130-134 (2011).

8. J. Bousquet, C. Bachert, G. Canonica, J. Mullol, P. Van Cauwenberge, C. Bindslev Jensen, W. Fokkens, J. Ring, P. Keith, R. Lorber, "Efficacy of desloratadine in intermittent allergic rhinitis: a GA2LEN study", Allergy, 64, 1516-1523 (2009).

9. P. Demoly, I. Dreyfus, H. DhivertDonnadieu, K. Mesbah, "Desloratadine for the treatment of cypress pollen-induced allergic rhinitis", Ann Allergy Asthma Immunol, 103, 260-266 (2009).

10. C. Bachert, C. J. Virchow, A. Plenker, "Desloratadine in the treatment of seasonal allergic rhinitis." Clin Drug Investig, 22, 43-52 (2002).

11. F. Horak, U. P. Stübner, R. Zieglmayer, A. G. Harris, "Effect of desloratadine versus placebo on nasal airflow and subjective measures of nasal obstruction in subjects with grass pollen-induced allergic rhinitis in an allergen-exposure unit", J Allergy Clin Immunol, 109, 956-961 (2002).

12. C. Bachert, M. Maurer, "Safety and efficacy of desloratadine in subjects with seasonal allergic rhinitis or chronic urticaria", Clin Drug Investig, 30, 109122 (2010).

13. R. Lorber, L. Salmun, M. Danzig, "Desloratadine is Effective At Relieving Nasal Congestion, as Demonstrated in Three Placebo-Controlled Trials in Patients with Seasonal Allergic Rhinitis." New Trends in Allergy V: Springer, 2002, pp. 252-259.

14. A. Nayak, E. Schenkel, "Desloratadine reduces nasal congestion in patients with intermittent allergic rhinitis." Allergy, 56, 1077-1080 (2001).

15. J. A. Wilken, R. L. Kane, A. K. Ellis, E. Rafeiro, M. P. Briscoe, C. L. Sullivan, J. H. Day, "A comparison of the effect of diphenhydramine and desloratadine on vigilance and cognitive function during treatment of ragweed-induced allergic rhinitis", Ann Allergy Asthma Immunol, 91, 375-385 (2003).

16. G. D. Raphael, J. T. Angello, M.-M. Wu, H. M. Druce, "Efficacy of diphenhydramine vs desloratadine and placebo in patients with moderate-tosevere seasonal allergic rhinitis", Ann Allergy Asthma Immunol, 96, 606-614 (2006).

17. K. Lukat, P. Rivas, A. Roger, M. Kowalski, U. Botzen, F. Wessel, F. Sanquer, I. Agache, I. Izquierdo, "A direct comparison of efficacy between desloratadine and rupatadine in seasonal allergic rhinoconjunctivitis: a randomized, double-blind, placebo-controlled study", $\boldsymbol{J}$ Asthma Allergy, 6, 31-39 (2013).

18. F. Horak, U. Petra Zieglmayer, R. Zieglmayer, A. Kavina, K. Marschall, U. Munzel, U. Petzold, "Azelastine nasal spray and desloratadine tablets in polleninduced seasonal allergic rhinitis: a pharmacodynamic study of onset of action 
and efficacy." Curr. Med. Res. Opin., 22, 151-157 (2006).

19. J. Day, M. Briscoe, E. Rafeiro, J. Ratz, "Comparative clinical efficacy, onset and duration of action of levocetirizine and desloratadine for symptoms of seasonal allergic rhinitis in subjects evaluated in the environmental exposure unit (EEU)", Int J Clin Pract, 58, 109-118 (2004).

20. C. Deruaz, A. Leimgruber, M. Berney, E. Pradervand, F. Spertini, "Levocetirizine better protects than desloratadine in a nasal provocation with allergen", $\boldsymbol{J}$ Allergy Clin Immunol, 113, 669-676 (2004).

21. S. Bhatia, F. M. Baroody, M. detineo, R. M. Naclerio, "Increased nasal airflow with budesonide compared with desloratadine during the allergy season", Arch. Otolaryngol Head Neck Surg, 131, 223228 (2005).

22. H. J. Crampton, "Comparison of ketotifen fumarate ophthalmic solution alone, desloratadine alone, and their combination for inhibition of the signs and symptoms of seasonal allergic rhinoconjunctivitis in the conjunctival allergen challenge model: a double-masked, placebo-and activecontrolled trial", Clin Ther, 25, 1975-1987 (2003).

23. C. Bachert, P. Kuna, F. Sanquer, P. Ivan, V. Dimitrov, M. Gorina, P. Van De Heyning, A. Loureiro, B. I. W. Group, "Comparison of the efficacy and safety of bilastine $20 \mathrm{mg}$ vs desloratadine $5 \mathrm{mg}$ in seasonal allergic rhinitis patients", Allergy, 64, 158-165 (2009).

24. W. E. Berger, W. R. Lumry, E. O. Meltzer, D. S. Pearlman, Eds. "Efficacy of desloratadine, $5 \mathrm{mg}$, compared with fexofenadine, $180 \mathrm{mg}$, in patients with symptomatic seasonal allergic rhinitis", Allergy \& Asthma Proceedings, 2006.

25. S. Reinartz, S. Overbeek, A. Kleinjan, C. van Drunen, G. J. Braunstahl, H. Hoogsteden, W. Fokkens, "Desloratadine reduces systemic allergic inflammation following nasal provocation in allergic rhinitis and asthma patients", Allergy, 60, 1301-1307 (2005).

26. A. Manjra, H. Nel, B. Maharaj, "Effect of desloratadine on patients with allergic rhinitis and exercise-induced bronchoconstriction: a placebo controlled study", J Asthma, 46, 156-9 (2009).

27. W. E. Berger, E. J. Schenkel, L. E. Mansfield, D. S. Group, "Safety and efficacy of desloratadine $5 \mathrm{mg}$ in asthma patients with seasonal allergic rhinitis and nasal congestion", Ann Allergy Asthma Immunol, 89, 485-491 (2002).

28. D. Tworek, M. Bocheńska-Marciniak, M. Kupczyk, P. Górski, P. Kuna, "The effect of 4 weeks treatment with desloratadine ( 5 mg daily) on levels of interleukin (IL)-4, IL-10, IL-18 and TGF beta in patients suffering from seasonal allergic rhinitis", Pulm Pharmacol Ther, 20, 244-249 (2007).

29. C. E. Baena-Cagnani, W. E. Berger, L. M. DuBuske, S. E. Gurné, P. Stryszak, R. Lorber, M. Danzig, "Comparative effects of desloratadine versus montelukast on asthma symptoms and use of $\beta 2$-agonists in patients with seasonal allergic rhinitis and asthma", Int Arch Allergy Immunol, 130, 307-313 (2003).

30. J. Bousquet, N. Khaltaev, A. A. Cruz, J. Denburg, W. Fokkens, A. Togias, T. Zuberbier, C. E. Baena-Cagnani, G. Canonica, C. Van Weel, "Allergic rhinitis and its impact on asthma (ARIA) 2008", Allergy, 63, 160-168 (2008).

31. K. Holmberg, A. B. Tonnel, I. Dreyfus, P. Olsson, J. Cougnard, K. Mesbah, P. Devillier, "Desloratadine relieves nasal congestion and improves quality-of-life in persistent allergic rhinitis", Allergy, 64, 1663-1670 (2009).

32. K. Kim, G. Sussman, J. Hébert, W. Lumry, B. Lutsky, D. Gates, "Desloratadine therapy for symptoms associated with perennial allergic rhinitis", Ann Allergy Asthma Immunol, 96, 460465 (2006).

33. J. Bousquet, C. Bachert, G. W. Canonica, J. Mullol, P. Van Cauwenberge, C. B. 
Jensen, W. J. Fokkens, J. Ring, P. Keith, G. Gopalan, "Efficacy of desloratadine in persistent allergic rhinitis-a GA2LEN study", Int Arch Allergy Immunol, 153, 395-402 (2010).

34. F. E. R. Simons, B. M. Prenner, A. Finn Jr, D. S. Group, "Efficacy and safety of desloratadine in the treatment of perennial allergic rhinitis", J Allergy Clin Immunol, 111, 617-622 (2003).

35. H. Lam, M. Tong, C. Van Hasselt, "Rhinitis symptoms and quality of life in patients with chronic perennial rhinitis treated with desloratadine", J Laryngol Otol, 121, 1151-1155 (2007).

36. P. Tassinari, N. R. Suárez, J. Centeno, J. V. Velásquez, H. Aguirre-Mariscal, S. N. G. Díaz, A. F. de Córdova Jerves, L. D. S. Group, "Desloratadine therapy improves allergic rhinitis symptoms in Latin American children aged 6 to 12 years", World Allergy Organ J, 2, $42-48$ (2009).

37. C. Cingi, F. Oghan, G. Eskiizmir, A. Yaz, A. Ural, N. Erdogmus, Eds. "Desloratadine-montelukast combination improves quality of life and decreases nasal obstruction in patients with perennial allergic rhinitis." International Forum of Allergy \& Rhinology, 2013.

38. D. Lee, M. Gardiner, K. Haggart, S. Fujihara, B. Lipworth, "Comparative effects of desloratadine, fexofenadine, and levocetirizine on nasal adenosine monophosphate challenge in patients with perennial allergic rhinitis", Clin Exp Allergy, 34, 650-3 (2004).

39. C. I. Bocşan, A. I. Bujor, N. Miron, Ş. C. Vesa, D. Deleanu, A. D. Buzoianu, "In vivo anti-inflammatory effect of $\mathrm{H} 1$ antihistamines in allergic rhinitis: a randomized clinical trial", Balk Med J, 32, 352-358 (2015).

40. G. Ciprandi, I. Cirillo, A. Vizzaccaro, E. Civardi, S. Barberi, M. Allen, G. L. Marseglia, "Desloratadine and levocetirizine improve nasal symptoms, airflow, and allergic inflammation in patients with perennial allergic rhinitis: a pilot study", Int Immunopharmacol, 5, 1800-1808 (2005).

41. M. Ciebiada, M. Górska-Ciebiada, L. M. DuBuske, P. Górski, "Montelukast with desloratadine or levocetirizine for the treatment of persistent allergic rhinitis", Ann Allergy Asthma Immunol, 97, 664671 (2006).

42. G. F. Wandalsen, C. Miranda, L. F. Ensina, F. Sano, R. B. Amazonas, J. M. d. Silva, D. Solé, "Association between desloratadine and prednisolone in the treatment of children with acute symptoms of allergic rhinitis: a double-blind, randomized and controlled clinical trial", Braz J Otorhinolaryngol, 83, 633-639 (2017).

43. A. Maaouia, M. Youssef, N. Leban, H. Foddha, J. B. Chiba-Ni, J. Zili, A. Noureddinehelal, A. Kassab, "Antioxidant and inflammatory status of Tunisian patients with chronic spontaneous urticaria and effect of desloratadine: a case-control study", Ann Med Biomed Sci, 2, 35-40 (2016).

44. J. Grob, P. Auquier, I. Dreyfus, J. Ortonne, "Quality of life in adults with chronic idiopathic urticaria receiving desloratadine: a randomized, double-blind, multicentre, placebo-controlled study", $\boldsymbol{J}$ Eur Acad Dermatol Venereol, 22, 87-93 (2008).

45. H. Kim, C. Lynde, "Impact of Desloratadine on Symptoms and Quality of Life in Subjects with Chronic Idiopathic Urticaria: A Multicenter, Practice-based Study", Arch Drug Inf, 1, 63-69 (2008).

46. J. M. Lachapelle, J. Decroix, A. Henrijean, P. P. Roquet-Gravy, A. De Swerdt, H. Boonen, N. Vastesaeger, "Desloratadine $5 \mathrm{mg}$ once daily improves the quality of life of patients with chronic idiopathic urticaria." J. Eur. Acad. Dermatol. Venereol., 20, 288-292 (2006).

47. J.-P. Ortonne, J.-J. Grob, P. Auquier, I. Dreyfus, "Efficacy and safety of desloratadine in adults with chronic 
idiopathic urticaria", Am J Clin Dermatol, 8, 37-42 (2007).

48. M. Augustin, S. Ehrle, "Safety and efficacy of desloratadine in chronic idiopathic urticaria in clinical practice: an observational study of 9246 patients", $\boldsymbol{J}$ Eur Acad Dermatol Venereol, 23, 292299 (2009).

49. E. Monroe, A. Finn, P. Patel, R. Guerrero, P. Ratner, D. Bernstein, D. U. S. Group, "Efficacy and safety of desloratadine $5 \mathrm{mg}$ once daily in the treatment of chronic idiopathic urticaria: a double-blind, randomized, placebo-controlled trial", $\boldsymbol{J}$ Am Acad Dermatol, 48, 535-541 (2003).

50. J. Ring, R. Hein, A. Gauger, E. Bronsky, B. Miller, D. S. Group, "Once-daily desloratadine improves the signs and symptoms of chronic idiopathic urticaria: a randomized, double-blind, placebo-controlled study", Int $\boldsymbol{J}$ Dermatol, 40, $72-76$ (2001).

51. B. P. Kolasani, R. Mudium, N. Reddy, "A comparative study of efficacy and safety of rupatadine versus desloratadine in patients with chronic idiopathic urticaria", Asian J Biomed Pharm Sci, 3, 17-19 (2013).

52. P. Potter, E. Mitha, L. Barkai, G. Mezei, E. Santamaría, I. Izquierdo, M. Maurer, "Rupatadine is effective in the treatment of chronic spontaneous urticaria in children aged 2-11 years", Pediatr Allergy Immunol, 27, 55-61 (2016).

53. P. Potter, A. Kapp, M. Maurer, G. Guillet, A. Jian, P. Hauptmann, A. Finlay, "Comparison of the efficacy of levocetirizine $5 \mathrm{mg}$ and desloratadine 5 $\mathrm{mg}$ in chronic idiopathic urticaria patients", Allergy, 64, 596-604 (2009).

54. M. Staevska, T. A. Popov, T. Kralimarkova, C. Lazarova, S. Kraeva, D. Popova, D. S. Church, V. Dimitrov, M. K. Church, "The effectiveness of levocetirizine and desloratadine in up to 4 times conventional doses in difficult-totreat urticaria", J Allergy Clin Immunol, 125, 676-682 (2010).
55. A. Khalaf, X. M. Liu, W. X. Sheng, J. Tan, A. Abdalla, "Efficacy and safety of desloratadine combined with dipyridamole in the treatment of chronic urticaria", $J$ Eur Acad Dermatol Venereol, 22, 487492 (2008).

56. G. Di Lorenzo, M. L. Pacor, P. Mansueto, M. E. Pellitteri, C. L. Bianco, V. Ditta, N. Martinelli, G. B. Rini, "Randomized placebo-controlled trial comparing desloratadine and montelukast in monotherapy and desloratadine plus montelukast in combined therapy for chronic idiopathic urticaria" J Allergy Clin Immunol, 114, 619-625 (2004).

57. D. Marquez, C. Ramonda, J. E. Lauxmann, C. A. Romero, V. L. Vukelic, C. Martinatto, B. Barrón, P. A. Novoa, A. J. Peixoto, M. Orías, "Uremic pruritus in hemodialysis patients: treatment with desloratidine versus gabapentin", Braz $\boldsymbol{J}$ Nephrol, 34, 148-152 (2012).

58. L. Juhlin, "Inhibition of cold urticaria by desloratadine", J Dermatolog Treat, 15, 51-9 (2004).

59. F. Siebenhaar, F. Degener, T. Zuberbier, P. Martus, M. Maurer, "High-dose desloratadine decreases wheal volume and improves cold provocation thresholds compared with standard-dose treatment in patients with acquired cold urticaria: a randomized, placebo-controlled, crossover study", J Allergy Clin Immunol, 123, 672-679 (2009).

60. M. Bi, C. Wang, F. Yang, "Effects of desloratadine citrate disodium combined with budesonide suspension on serum IgE, EOS and inflammatory factors in patients with CRS after endoscopic sinus surgery", J Hainan Med, 23, 57-60 (2017).

61. R. Barazi, H. Adib, G. Ziadeh, E. Khalifeh, H. Tamim, "The effect of desloratadine on chronic otitis media with effusion in children requiring grommet", $\boldsymbol{J}$ Otol Rhinol, 6, 2 (2017).

62. H. E. Lee, I. K. Chang, Y. Lee, C. D. Kim, Y. J. Seo, J. H. Lee, M. Im, "Effect of antihistamine as an adjuvant treatment of isotretinoin in acne: a randomized, 
controlled comparative study", J Eur Acad Dermatol Venereol, 28, 1654-1660 (2014).

63. T. N. Van, L. D. Thi, H. N. Trong, T. C. Van, T. T. Minh, P. P. T. Minh, N. D. Huu, V. T. Cam, M. Le Huyen, K. T. Hau, "Efficacy of oral isotretinoin in combination with desloratadine in the treatment of common vulgaris acne in Vietnamese patients", Open Access Maced J Med Sci, 7, 217-220 (2019).
64. S. A. Dhaher, Z. M. Jasim, "The adjunctive effect of desloratadine on the combined azithromycin and isotretinoin in the treatment of severe acne: randomized clinical trial", J Dermatol Dermatol Surg, 22, 21-25 (2018). 


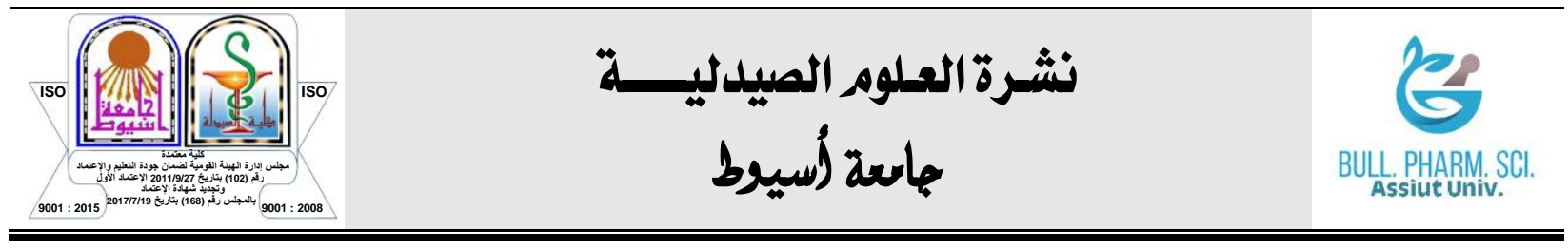

الفعالية السريرية لمضادات الهيستامين غير المهدئة ديسلور اتادين في تدبير حالات

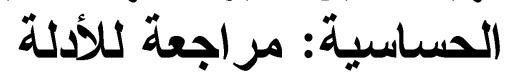

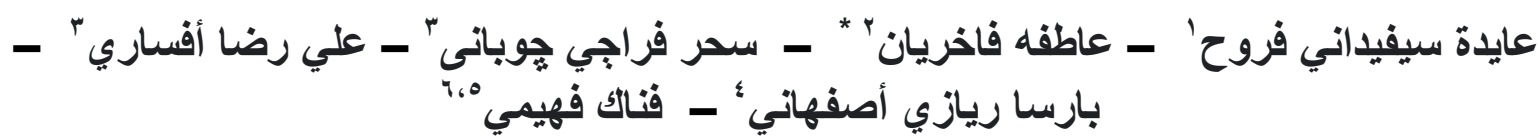

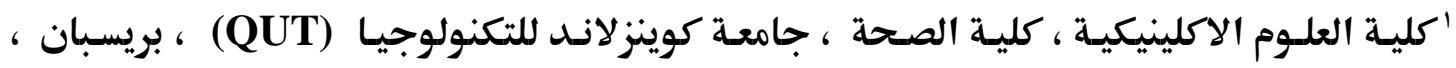

$$
\text { كوينز لاند ، أستراليا }
$$

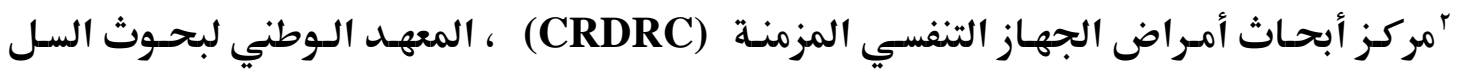

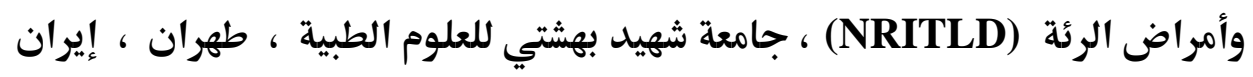

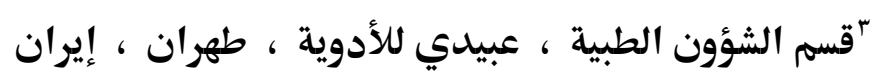

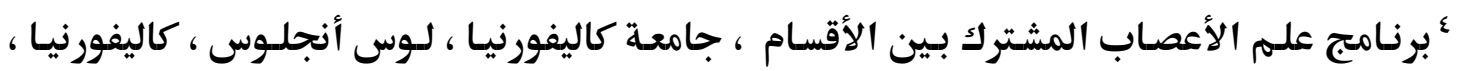

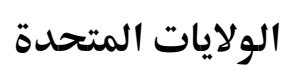

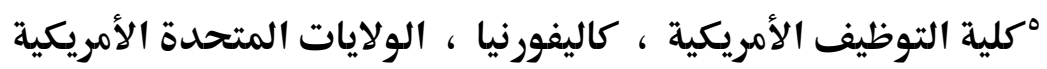

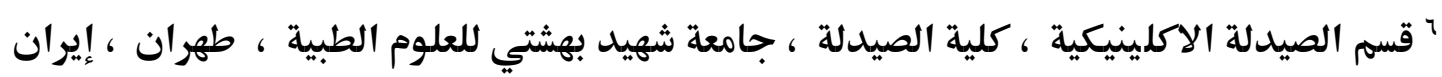

ديسلور اتادين هو مضاد للهستامين ثلاثي الحلقات جديد نسبيًا من الجيل الثاني دخل حيز الاستخدام

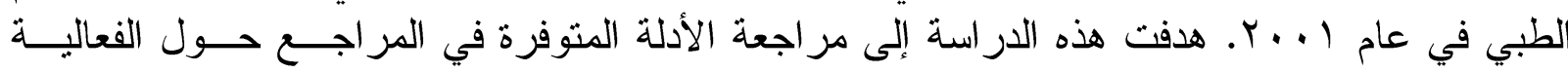

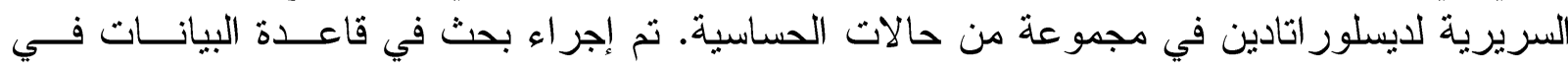

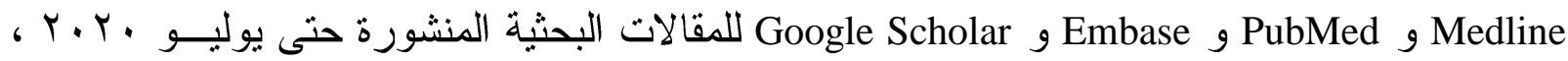

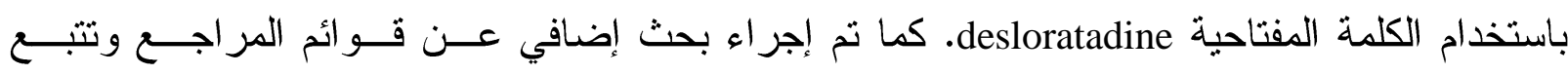

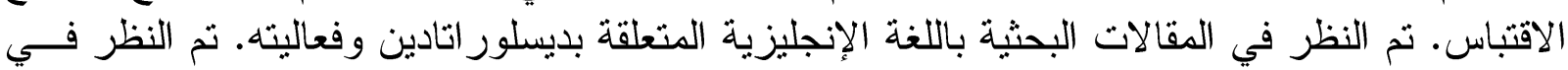

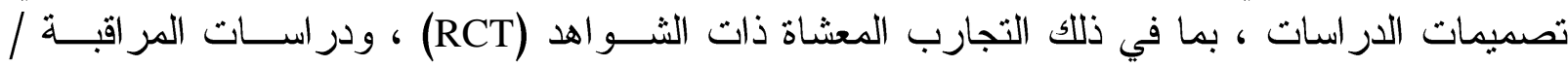

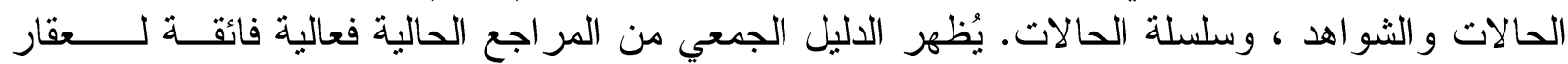

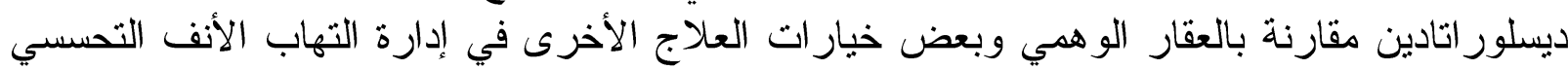

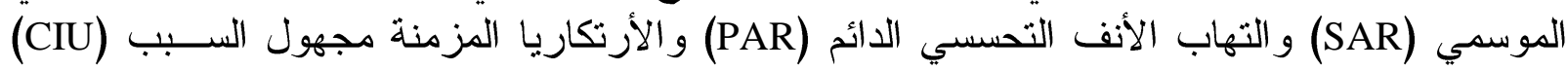

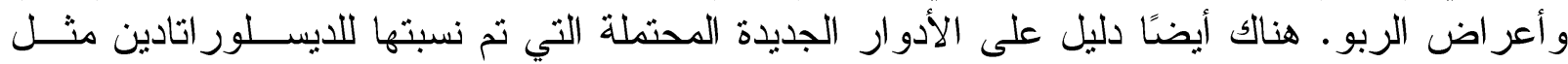

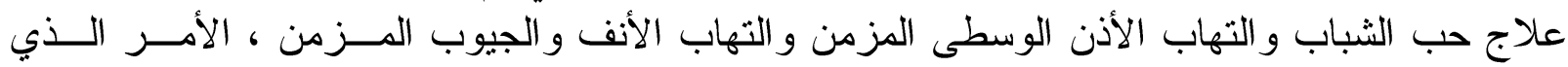

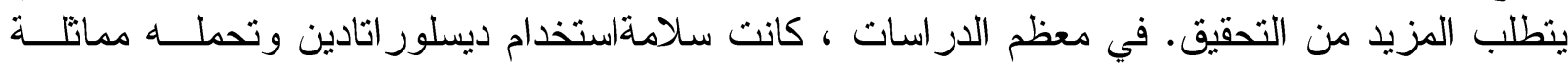
للعقار الوهي. تشير الدلاثل الحالية إلى أن ديسلور اتادين هو خيار مثالي لمعظم حالات الحساسية نظرًا 


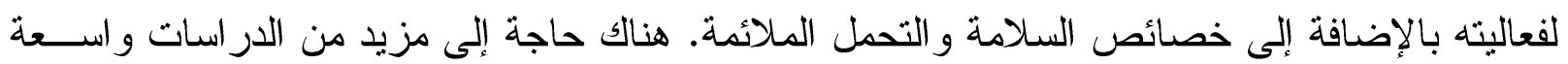

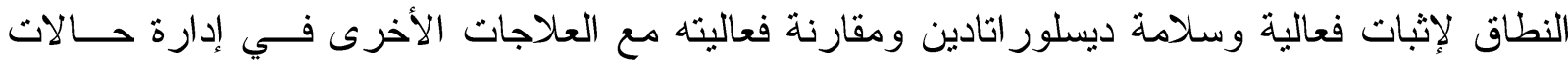

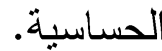

